\title{
Multiproxy sedimentological and geochemical analyses across the Lower- Middle Pleistocene boundary: chemostratigraphy and paleoenvironment of the Chiba composite section, central Japan
}

Kentaro Izumi ${ }^{*}$, Yuki Haneda ${ }^{2}$, Yusuke Suganuma ${ }^{3,4}$, Makoto Okada $^{5}$, Yoshimi Kubota $^{6}$, Naohisa Nishida ${ }^{7}$ Moto Kawamata ${ }^{4}$ and Takuya Matsuzaki ${ }^{8}$

\begin{abstract}
The Chiba composite section (CbCS) in the Kokumoto Formation, Kazusa Group, central Japan is a thick and continuous marine succession that straddles the Lower-Middle Pleistocene boundary and the well-recognized Matuyama-Brunhes paleomagnetic polarity boundary. Although recent studies extensively investigated the CbCS, its chemostratigraphy, particularly around the Lower-Middle Pleistocene boundary, is poorly understood. Therefore, in this study, we performed multiproxy sedimentological and geochemical analyses of the CbCS, including the Chiba section, which is the Global Boundary Stratotype Section and Point for defining the base of the Middle Pleistocene Subseries. The aim of these analyses is to establish the high-resolution chemostratigraphy and to reconstruct the paleoenvironments of its sedimentary basin in detail. We used the K/Ti ratio as a broad proxy for the clastic material grain size of the sediments. Although the $\mathrm{K} / \mathrm{Ti}$ ratio generally varies throughout the studied interval, the K/Ti ratio especially during Marine Isotope Stage (MIS) 19a shows a variation pattern like those of the foraminiferal oxygen isotope $\left(\delta^{18} \mathrm{O}\right)$ records. The records of the $\mathrm{C} / \mathrm{N}$ ratio of bulk samples and carbon isotope ratio of the organic carbon $\left(\delta^{13} \mathrm{C}_{\text {org }}\right.$ ) suggest that the organic matter in the CbCS sediments during MIS $19 \mathrm{c}$ mostly originated from marine plankton, whereas the organic matter during MIS 18 and 19a was characterized by a mixture of marine plankton and terrestrial plants. These records are clearly indicative of changes in mixing ratio of marine vs. terrestrial organic matter in association with glacial-interglacial cycles from the late MIS 20 to the early MIS 18. In addition, we calculated the mass accumulation rates (MARs) of organic carbon, biogenic carbonate, and terrigenous material for quantitative interpretations on the paleoenvironmental changes. MAR calculations revealed that the contribution of marine organic carbon relative to terrestrial organic carbon increased during MIS 19c, and that the contribution of the terrigenous material relative to biogenic carbonate decreased during MIS 19c.

(Continued on next page)
\end{abstract}

\footnotetext{
*Correspondence: izumi@chiba-u.jp

${ }^{1}$ Faculty \& Graduate School of Education, Chiba University, 1-33 Yayoi-Cho, Inage-Ku, Chiba-shi, Chiba 263-8522, Japan

Full list of author information is available at the end of the article
}

Springer Open (c) The Author(s). 2021 Open Access This article is licensed under a Creative Commons Attribution 4.0 International License, which permits use, sharing, adaptation, distribution and reproduction in any medium or format, as long as you give appropriate credit to the original author(s) and the source, provide a link to the Creative Commons licence, and indicate if changes were made. The images or other third party material in this article are included in the article's Creative Commons licence, unless indicated otherwise in a credit line to the material. If material is not included in the article's Creative Commons licence and your intended use is not permitted by statutory regulation or exceeds the permitted use, you will need to obtain permission directly from the copyright holder. To view a copy of this licence, visit http://creativecommons.org/licenses/by/4.0/. 


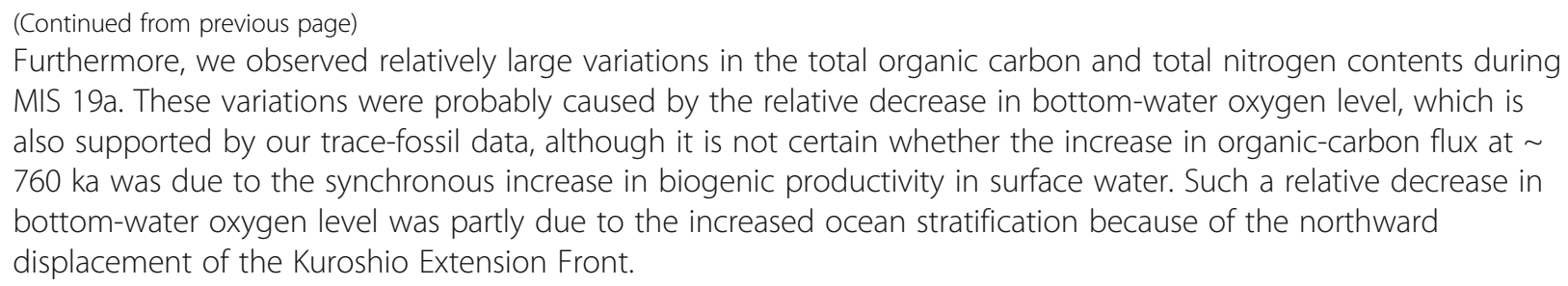

Keywords: Chemostratigraphy, Chiba composite section, GSSP, Kokumoto Formation, Organic matter, Paleoenvironment, Pleistocene, Trace fossils, XRF

\section{Introduction}

The Lower to Middle Pleistocene is an important geological period that is characterized by gradual changes in the climate systems that affected the evolution of biota (Maasch 1988; Mudelsee and Schulz 1997; Mudelsee and Stattegger 1997; Raymo et al. 1997; Head and Gibbard 2005; Clark et al. 2006; Head et al. 2008; Elderfield et al. 2012; Head and Gibbard 2015). The Chiba composite section (CbCS) in the Kokumoto Formation of central Japan is a thick and continuous marine succession that straddles the Lower-Middle Pleistocene boundary and the wellrecognized Matuyama-Brunhes paleomagnetic polarity boundary (M-B boundary) (Niitsuma 1976; Okada and Niitsuma 1989; Suganuma et al. 2015; Nishida et al. 2016; Okada et al. 2017; Suganuma et al. 2018; Haneda et al. 2020a). Because the M-B boundary serves as the primary guide for the Lower-Middle Pleistocene stage boundary (Head and Gibbard 2005), the Chiba section, which is one of the main sections of the CbCS (see Section 2 for a detailed description) that also contains many key tephra layers and thus chronostratigraphic tie-points, has recently been determined as the Global Boundary Stratotype Section and Point (GSSP) for the base of the Middle Pleistocene Subseries (Suganuma et al. 2021). Furthermore, the $\mathrm{M}-\mathrm{B}$ boundary is underlain by a distinctive and widespread tephra deposit, Byk-E (also known as the OntakeByakubi Tephra: Takeshita et al. 2016), which allows the boundary to be identified also in successions in other parts of Japan.

Because the Kokumoto Formation is well-exposed along the Yoro River of the Boso Peninsula, central Japan, there have been numerous studies on the formation based on litho-, bio-, tephro-, magneto-, and oxygen-isotope stratigraphy (as reviewed by Kazaoka et al. 2015; Suganuma et al. 2018). In addition, the sedimentological features of the Kokumoto Formation have also been extensively investigated (Katsura 1984; Ito 1992; Ito and Katsura 1992; Nakamura et al. 2007; Nishida et al. 2016; Takao et al. 2020). However, the detailed chemostratigraphy (i.e., organic carbon isotope ratio, the contents of organic elements such as carbon and nitrogen, and major inorganic elements) of the CbCS, particularly near the Lower-Middle Pleistocene boundary, remains poorly understood.

Therefore, the aims of this study are to (1) establish the chemostratigraphy of the CbCS in detail and (2) reconstruct the paleoenvironmental changes recorded in the CbCS. Because the Boso Peninsula faces the Pacific Ocean where the subtropical Kuroshio and subarctic Oyashio currents meet at the southern margin of the Subarctic Front (Fig. 1), these data are especially important and unique for a better understanding of the fundamental changes in the ocean and climate systems of the northwestern Pacific Ocean across the Lower-Middle Pleistocene boundary.

\section{Geological setting and chronological framework}

The Kazusa Group outcrops widely in the middle region of the Boso Peninsula, central Japan. It unconformably overlies the Miocene and Pliocene Miura Group and is overlain by the Middle and Upper Pleistocene Shimosa Group (Fig. 2). The Kazusa Group, which comprises the fills of the Kazusa fore-arc basin, was deposited in the basin plain, submarine fan, slope, shelf, and coastal environments (Katsura 1984; Ito and Katsura 1992). The thickest succession (up to $3000 \mathrm{~m}$ ) crops out along the Yoro River, where the outcrops of the Kazusa Group can be observed continuously. Therefore, numerous studies based on lithostratigraphy, biostratigraphy, tephrostratigraphy, paleomagnetism, and oxygen-isotope stratigraphy have focused on the type section of the Kazusa Group (as reviewed by Kazaoka et al. 2015). The Kazusa Group includes the following 14 main lithostratigraphic units, in ascending order: the Kurotaki, Katsuura, Namihana, Ohara, Kiwada, Otadai, Umegase, Kokumoto, Kakinokidai, Ichijiku, Chonan, Mandano, Kasamori, and Kongochi formations (Tokuhashi and Endo 1984; Kazaoka et al. 2015; Fig. 2).

The Kokumoto Formation, which is the middle part of the Kazusa Group, is generally $350-400$ m thick and is mainly composed of alternating sandstone, siltstone, and some distinct tephra layers (Kazaoka et al. 2015; Nishida et al. 2016; Fig. 2). One of the most distinctive and important key tephra layers is the Byk-E tephra (see 


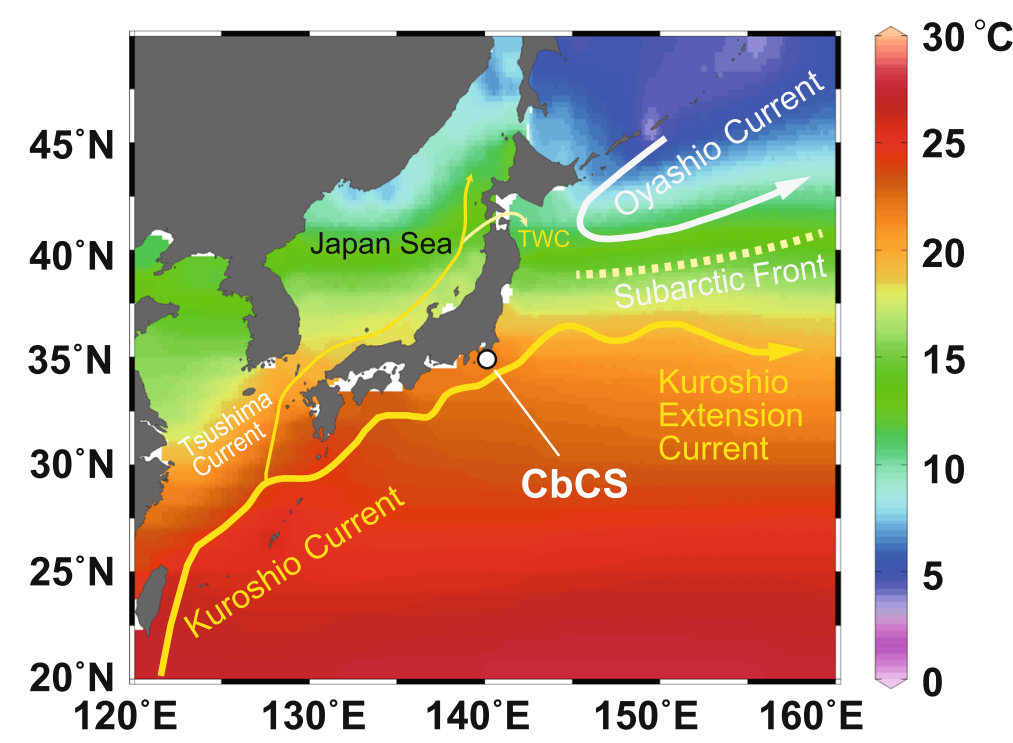

Fig. 1 Oceanographic circulation in summer around Japan. The CbCS (white circle) is located in the middle of the Boso Peninsula, central Japan. Positions of major ocean currents are based on Brown et al. (2001). Ocean temperature gradients are from World Ocean Atlas 2013 (Locarnini et al. 2013), which was drawn using Ocean Data View software (Schlitzer 2015). This figure was redrawn after Suganuma et al. (2018)

Kazaoka et al. 2015). The Kokumoto Formation represents an expanded and well-exposed sedimentary succession across the Lower-Middle Pleistocene boundary, especially at the CbCS. The CbCS comprises the Yoro River section, the Yoro-Tabuchi, Yanagawa, Urajiro, and Kokusabata sections (Suganuma et al. 2018; GSSP proposal group 2019; Fig. 2; see also Suganuma et al. 2021). The Chiba section is an extension of the Yoro River section (Suganuma et al. 2021, for details). These sections are adjacent and contiguous throughout the LowerMiddle Pleistocene boundary interval (Fig. 2). The lithology of the CbCS is dominated by bioturbated siltstones, as described by previous studies (e.g., Suganuma et al. 2018). Although there are minor sandy beds, particularly in the lower part of the succession, the $\mathrm{CbCS}$ is generally interpreted to be a continuous depositional unit (Nishida et al. 2016). For more detailed descriptions on the lithology of the Kokumoto Formation, see Kazaoka et al. (2015).

The Yoro-Tabuchi and Yanagawa sections of the $\mathrm{CbCS}$ show no evidence of slump scars or unconformities and are composed mainly of hemipelagites (Nishida et al. 2016). In addition, Nishida et al. (2016) reported ichnogenera, mainly from these sections, which are typical of deep-sea siliciclastic systems (Hubbard et al. 2012; Uchman and Wetzel 2012; Wetzel and Uchman 2012). Therefore, it is generally assumed that the $\mathrm{CbCS}$ was deposited on the continental slope under generally stable conditions (Nishida et al. 2016), which were free of the wave/current influences that are common in shallow shelf environments (Nishida et al. 2016). The trace fossil assemblage of the $\mathrm{CbCS}$ is the characteristic of the Zoophycos ichnofacies (Nishida et al. 2016). Based on a compilation of the marine sediment cores from the world's oceans, it has been suggested that Zoophycos occurs only at water depths of more than 800-1000 m, although there are significant variations in its bathymetric distribution (Löwemark and Werner 2001). Importantly, burrows assignable to Zoophycos have never been found in shallow water settings (Löwemark and Werner 2001), further supporting the conclusion that the $\mathrm{CbCS}$ was deposited on the continental slope.

Highly detailed bio-, tephro-, magneto-, and oxygen isotope stratigraphic investigations have been performed on the Kokumoto Formation so far, allowing the integrated stratigraphy of the CbCS to be established (e.g., Suganuma et al. 2015, 2018, 2021; Okada et al. 2017; Simon et al. 2019; Haneda et al. 2020a, b; Kameo et al. 2020). An age model of the CbCS proposed in a previous study based on the detailed oxygen isotope $\left(\delta^{18} \mathrm{O}\right)$ stratigraphy yielded a depositional age spanning the late Marine Isotope Stage (MIS) 20 through the early MIS 18 (see Fig. 6 in Suganuma et al. 2018). This model also suggests that the minimum sedimentation rate, which occurred during an interval of maximum flooding, was $44 \mathrm{~cm} / \mathrm{kyr}$. The M-B boundary is located $\sim 110 \mathrm{~cm}$ above the Byk-E tephra layer in the Chiba section (Okada et al. 2017) and lies in an interval with a sedimentation rate of $89 \mathrm{~cm} / \mathrm{kyr}$ (Suganuma et al. 2018). MIS substages (MIS 19c, 19b, and 19a) have also been assigned based on the climatic variables proposed by Nomade et al. (2019); MIS 19c corresponds to the climatically stable part of Stage 19, MIS 19b to the first climatic cooling stage, and MIS 19a to the most unstable 

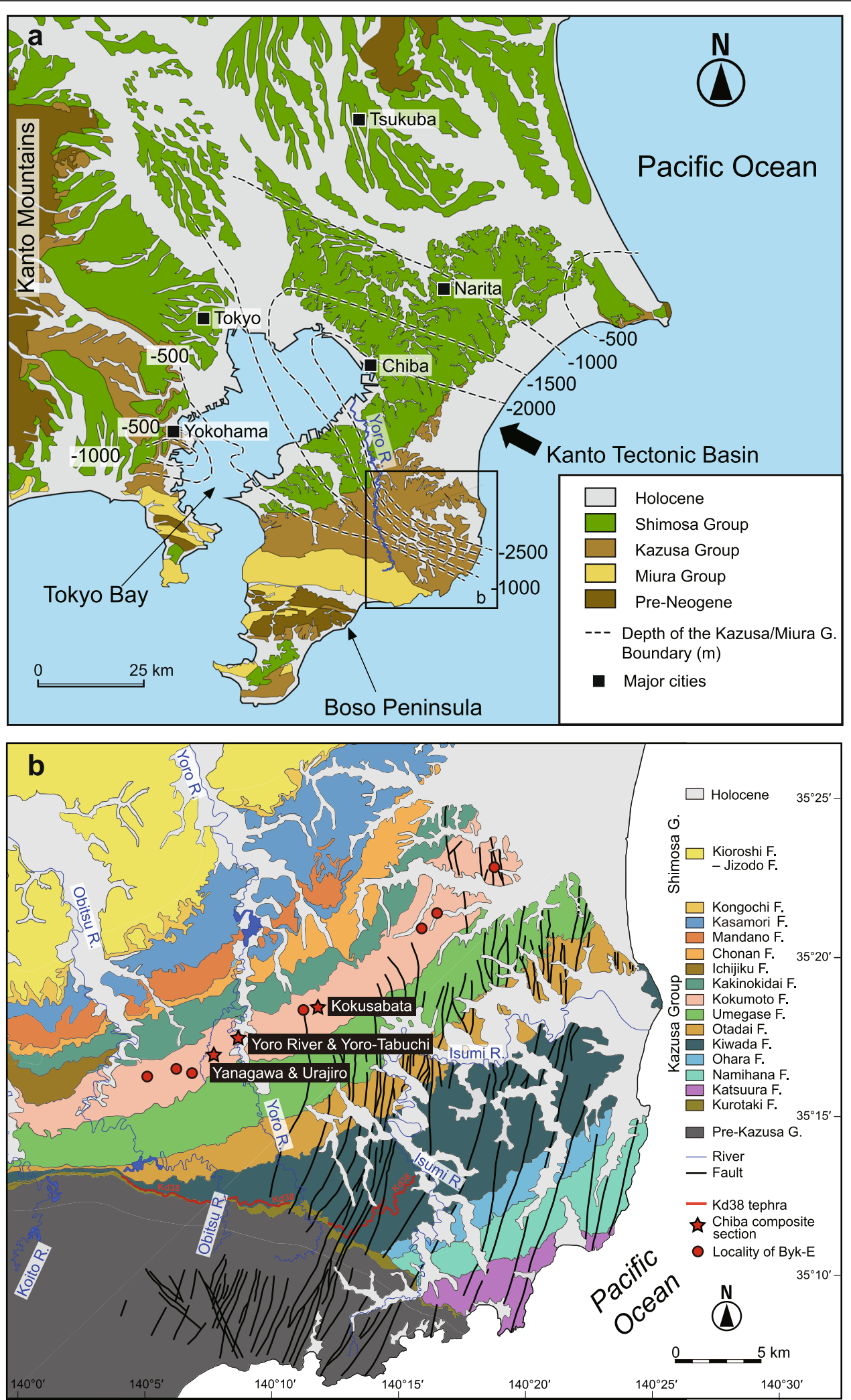

Fig. 2 a A simplified geological map of the entire Kanto area, which is redrawn after Kazaoka et al. (2015) and Suganuma et al. (2018). Box indicates location of a detailed geological map in $\mathbf{b}$. $\mathbf{b}$ A detailed geological map of the Boso Peninsula, highlighting stratigraphy of the Kazusa Group and location of CbCS. Panel b is redrawn after Suganuma et al. (2018) and GSSP proposal group (2019) 


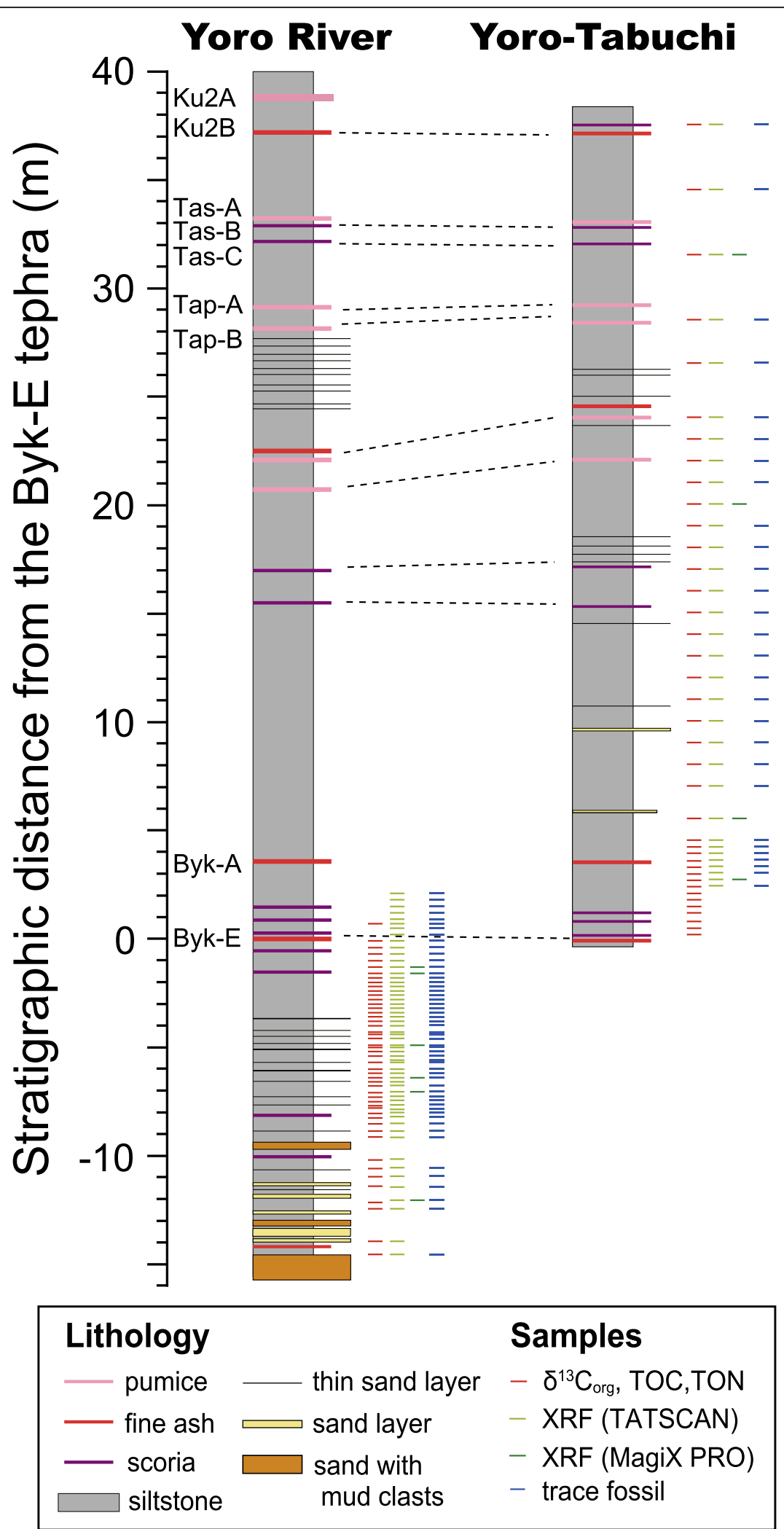

Fig. 3 Lithological logs of the Yoro River and Yoro-Tabuchi sections. The horizons of the samples for geochemical analyses (CN analysis, and XRF analysis) are highlighted. Logs are modified from Suganuma et al. (2018). The Lower-Middle Pleistocene boundary corresponds with the base of the Byk-E tephra (at $0 \mathrm{~m}$ in the lithological logs) 
part of Stage 19 (Haneda et al. 2020b). The astronomical ages for the stage and substage boundaries have been estimated to be $787.5 \mathrm{ka}$ (MIS 20/19c), $773.9 \mathrm{ka}$ (MIS 19c-19b), $770.1 \mathrm{ka}$ (MIS 19b-19a), and $756.9 \mathrm{ka}$ (MIS $19 \mathrm{a} / 18$ ), based on the age model for the CbCS by Suganuma et al. (2018) (Haneda et al. 2020b).

\section{Methods}

In this study, high-resolution multiproxy analyses were performed on siltstone samples collected from the Yoro River and Yoro-Tabuchi sections. Samples used for Xray fluorescence analysis, dry bulk density analysis, and trace fossil analysis are from the 1 inch-diameter cores (paleomagnetic cores), which were previously taken from the outcrops for paleomagnetic measurements (Okada et al. 2017; Simon et al. 2019). The lithological logs of the Yoro River and Yoro-Tabuchi sections are shown in Fig. 3 (see also Fig. 5 in the GSSP proposal group (2019)). The stratigraphic level for each sample (for all analyses) was taken to be the stratigraphic distance from the Byk-E tephra at the Yoro-River section (Suganuma et al. 2018, 2021; GSSP proposal group 2019). The Lower-Middle Pleistocene boundary corresponds to the base of the Byk-E tephra ( $0 \mathrm{~m}$ in the lithological logs in Fig. 3).

Samples analyzed by this study cover a $\sim 55$-m-thick interval that ranges from 794 ka (late MIS 20) to $756 \mathrm{ka}$ (early MIS 18).

\subsection{X-ray fluorescence analysis of major elements}

A total of 90 paleomagnetic cores with ca. 0.2 to 1.6 (average $=0.43) \mathrm{kyr}$ resolution were subjected to X-ray fluorescence (XRF) core-scanning analysis. The measurement samples were collected from the same or closely similar horizons as those for the samples used for the organic geochemical analysis (see detailed methods in the next section). The XRF core scanning analysis was performed using the nondestructive XRF core-imaging scanner TATSCAN-F2 installed at the Center for Advanced Marine Core Research, Kochi University, Japan (Sakamoto et al. 2006). The TATSCAN-F2 is designed to allow for rapid elemental scanning through energydispersive-type XRF (EDXRF) spectroscopy (Sakamoto et al. 2006). Although it can measure the elemental fluorescence intensity of the surface of the sediment samples (Sakamoto et al. 2006), the analytical data are semi-quantitative. The TATSCAN-F2 employs a new Xray detector with a rhodium $(\mathrm{Rh})$ target that can generate X-rays with a five-times higher intensity compared with standard EDXRF instruments (Sakamoto et al. 2006).

During the analysis using the TATSCAN-F2, the Xrays were projected with an analytical spot diameter of 7 $\mathrm{mm}$ using an X-ray tube voltage of $30 \mathrm{kV}$ and an appropriate X-ray tube current of 0.01-1.0 mA; this was performed to ensure that the X-ray intensity was sufficient. The obtained dataset of the concentrations of the major elements is tentatively represented as the weight percentages of their oxides (e.g., $\mathrm{Na}_{2} \mathrm{O}, \mathrm{MgO}, \mathrm{Al}_{2} \mathrm{O}_{3}$, $\mathrm{SiO}_{2}, \mathrm{P}_{2} \mathrm{O}_{5}, \mathrm{~S}, \mathrm{~K} 2 \mathrm{O}, \mathrm{CaO}, \mathrm{TiO}_{2}, \mathrm{MnO}$, and $\mathrm{Fe}_{2} \mathrm{O}_{3}$ ), except for sulfur. Reproducibility of the measurements, which was calculated as the standard deviation of the measured values of repeated measurements divided by the average of the repeatedly measured values, was \pm $0.48 \% \quad\left(\mathrm{Na}_{2} \mathrm{O}\right), \quad 0.24 \% \quad(\mathrm{MgO}), \quad 0.14 \% \quad\left(\mathrm{Al}_{2} \mathrm{O}_{3}\right), 0.23 \%$ $\left(\mathrm{SiO}_{2}\right), \quad 0.05 \%\left(\mathrm{P}_{2} \mathrm{O}_{5}\right), \quad 0.01 \%(\mathrm{~S}), 0.04 \%\left(\mathrm{~K}_{2} \mathrm{O}\right), \quad 0.29 \%$ $(\mathrm{CaO}), 0.02 \%\left(\mathrm{TiO}_{2}\right), 0.01 \%(\mathrm{MnO})$, and $0.22 \%\left(\mathrm{Fe}_{2} \mathrm{O}_{3}\right)$ (Sakamoto et al. 2006).

In addition, to further evaluate the abundance of each element obtained by the TATSCAN-F2 analysis (i.e., semi-quantitative analysis), a conventional (i.e., quantitative) XRF analysis was conducted for ten samples using the Magix PRO+PW2440/00 (Malvern Panalytical) installed at the Center for Advanced Marine Core Research. During measurements, an X-ray tube voltage was $32-60 \mathrm{kV}$ and the appropriate $\mathrm{X}$-ray tube current was 66-125 mA. For conventional XRF analysis, dry sediment samples were calcined at $950{ }^{\circ} \mathrm{C}$ for $6 \mathrm{~h}$ before making glass beads. Subsequently, glass bead samples were prepared by fusing $0.5 \mathrm{~g}$ of the calcined sediment samples with $5.0 \mathrm{~g}$ lithium tetraborate in a Pt crucible at $1250{ }^{\circ} \mathrm{C}$. The weight of the sediment sample and lithium tetraborate was measured using an electronic balance (measurement error $=0.1 \mathrm{mg}$ ). Each sample was analyzed three times, and the average value was used as the abundance of each element.

Finally, to compare the results obtained from the TATSCAN-F2 and those obtained from Magix PRO appropriately, we performed a correlation analysis.

\subsection{Carbon and nitrogen analyses}

A total of 89 samples with ca. 0.2 to 1.7 (average $=0.43$ ) kyr resolution were collected from the Yoro River and Yoro-Tabuchi sections, and their total organic carbon (TOC), total nitrogen (TN), and stable organic carbon isotope $\left(\delta^{13} \mathrm{C}_{\text {org }}\right)$ values were analyzed. In addition, the $\mathrm{C} / \mathrm{N}$ ratio $(=\mathrm{TOC} / \mathrm{TN})$ of each sample was calculated using the obtained data. The samples were treated with $1 \mathrm{~N} \mathrm{HCl}$ several times at room temperature to remove the carbonate fraction. Afterward, the samples were washed with distilled water until neutralized and then dried at $110{ }^{\circ} \mathrm{C}$. The TOC, TN, and $\delta^{13} \mathrm{C}_{\text {org }}$ values were measured using an elemental analyzer (Flash2000, ThermoFisher Scientific Ltd.) and a stable isotope mass spectrometer (MAT253, ThermoFisher Scientific Ltd.) at the Department of Geology and Paleontology, National Museum of Nature and Science, Japan. A few milligrams of each sample were sealed in Sn foil for the measurements 
of TOC, TN, and $\delta^{13} \mathrm{C}_{\mathrm{org}}$. During the measurements, the test sample was heated to $1000{ }^{\circ} \mathrm{C}$ in the furnace of the elemental analyzer, and the resulting purified $\mathrm{N}_{2}$ and $\mathrm{CO}_{2}$ gas was fed directly into the mass spectrometer using pure helium as the carrier gas. We performed the measurements on a working standard (L-Alanine; $\delta^{13} C_{\text {org }}=-18.50 \%$ ) with every sixth sample to calibrate the measured isotopic values with respect to the Vienna Pee Dee Belemnite (VPDB).

\subsection{Measurement of dry bulk density}

To calculate the mass accumulation rate of the specific material using the results of our XRF and organic geochemical $(\mathrm{C}, \mathrm{N})$ analyses, the dry bulk density of the $\mathrm{CbCS}$ sediments was calculated. Eighty-three paleomagnetic cores with ca. 0.2 to 2.8 (average $=0.46$ ) $\mathrm{kyr}$ resolution were measured for size (diameter, length) and weight. The size and weight were measured by using an electronic caliper and an electronic balance, respectively. The volume of each paleomagnetic core was calculated using its diameter and length, and subsequently, the dry bulk density of each paleomagnetic core was calculated using the volume and weight. The measurement errors of the electronic caliper and electronic balance are $0.1 \mathrm{~mm}$ and $0.01 \mathrm{~g}$, respectively. However, due to some knotty-shaped paleomagnetic cores, the actual measurement error of the size (diameter, length) of paleomagnetic cores may be $\sim 1 \mathrm{~mm}$. Therefore, the relative error of the dry bulk density may be quite large (probably up to $\sim 15 \%$ ), especially in the case of some knotty-shaped paleomagnetic cores.

\subsection{Analysis of trace fossils}

Eighty-three paleomagnetic cores with ca. 0.2 to 2.8 (average $=0.46)$ kyr resolution were subjected to the observation and analysis of trace fossils. These paleomagnetic cores were cut perpendicular to the bedding planes. Trace fossils of the polished surface of the paleomagnetic cores were observed. Afterward, the burrow size of the most abundant trace fossil (the ichnogenus Phycosiphon in the case of this study; Fig. 4) was measured using an image-analysis software ImageJ. When analyzing the temporal change in the size of Phycosiphon, the burrow diameter on the cross section was used in this study because it is commonly interpreted that the burrow diameter reflects the body diameter of the trace-maker. In this study, the burrow diameter of the analyzed trace fossil (i.e., Phycosiphon) is defined as the short axis of the cross section of the burrow, assuming that the burrow shape is cylindrical (e.g., Bednarz and McIlroy 2009) and the effect of compaction of the sediments is small (e.g., Izumi et al. 2017). In addition, the maximum burrow diameter represents a biological parameter of the trace-maker. Namely, the maximum burrow diameter preserves a record of the largest infaunal organism present at a given time, which is linked with relative oxygen levels correlated with body size based on physiological oxygen demands (Boyer and Droser 2011 and references therein).

In the case of Phycosiphon, this ichnogenus is a burrow tube filled with dark-colored, fine-grained material, which is generally defined as a "core," and the core is surrounded by pale-colored, coarser-grained material, which is generally defined as a "mantle" (e.g., Kern 1978; Goldring et al. 1991; Wetzel and Bromley 1994; Izumi 2014; see also Fig. 4). As for the paleoecological information of Phycosiphon, this ichnogenus has been regarded as a trace produced by a subsurface deposit feeder (e.g., Kern 1978; Wetzel and Bromley 1994), and the infill of the core has been interpreted as fecal material (e.g., Ekdale and Lewis 1991; Bednarz and McIlroy 2009). Based on the formation model of Phycosiphon (e.g., Wetzel and Bromley 1994; Bromley 1996; Seilacher 2007),
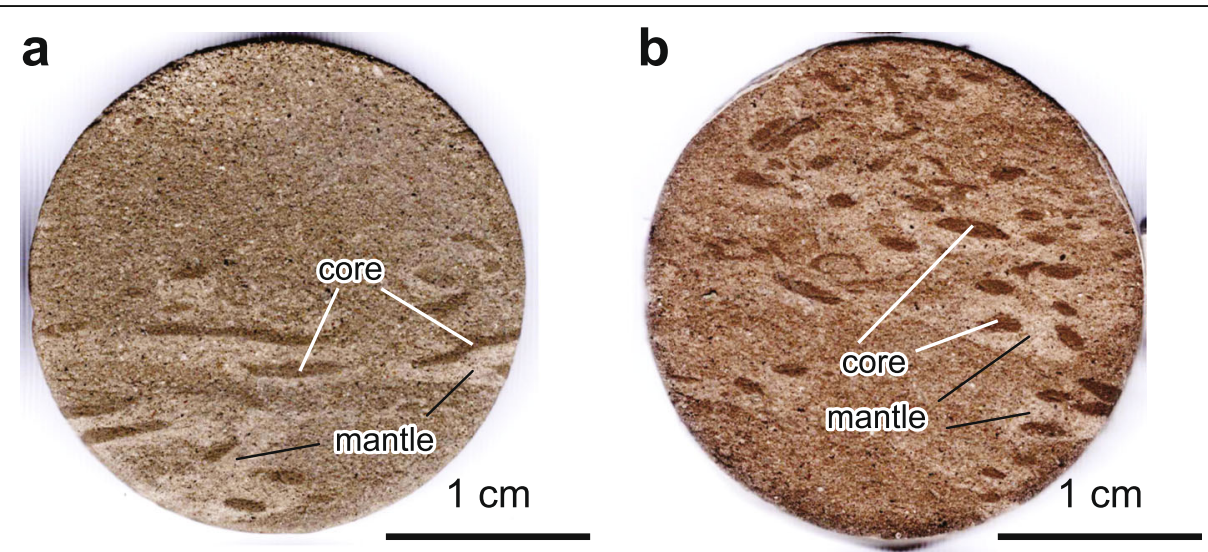

Fig. 4 Scan images of the selected samples of the polished paleomagnetic core. a Sample ID: TB3-37. b Sample ID: TB3-53. The paleomagnetic cores were cut perpendicular to bedding planes, thus, the upward direction of these images represent stratigraphically higher direction. Note abundant Phycosiphon in the surface. In addition, the core and mantle of Phycosiphon can clearly be observed 
the diameter of the core directly reflects the body diameter of the trace-maker.

\section{Results}

In this study, the main results are shown using graphs to illustrate the temporal patterns. The $x$-axis of each graph is based on the established age model (Suganuma et al. 2018). For the stratigraphic distance of each sample, see Supplementary Tables in Additional files.

\subsection{Concentrations of major inorganic elements}

Data obtained by TATSCAN-F2 and Magix PRO analyses are summarized in Table S1 (see Additional files). The absolute values of each element concentration are different in TATSCAN-F2 and Magix PRO partly due to the different sample conditions and analytical settings. However, the values of $\mathrm{CaO}$ obtained by TATSCAN-F2 and Magix PRO show strong positive correlation $(r=$ 0.87; see Fig. 5), while the values of low-concentration elements such as $\mathrm{K}_{2} \mathrm{O}$ and $\mathrm{TiO}_{2}$ obtained by these two analytical instruments do not show strong correlation (Fig. 5; see also Table S1 in Additional files).

The temporal trends of sedimentologically and paleoceanographically important proxies $(\mathrm{K} / \mathrm{Ti}$ ratio, and $\mathrm{Ca} /$ Ti ratio, respectively) are shown in Figs. 6 and 7, respectively; these are discussed in detail later in Section 5 . The results of the correlation analysis for these proxies are also presented in Fig. 5. The $\mathrm{K} / \mathrm{Ti}$ and $\mathrm{Ca} / \mathrm{Ti}$ values obtained by TATSCAN-F2 are highly consistent with those by Magix PRO, which is supported by the high correlation coefficient $(r=0.91$ and 0.97 , respectively; see Fig. 5, and Table S1 in Additional files). Thus, the temporal trends of $\mathrm{K} / \mathrm{Ti}$ and $\mathrm{Ca} / \mathrm{Ti}$ ratios obtained by TATSCAN-F2 are discussed in Section 5.

\subsection{TOC, TN, C/N ratio, and $\delta^{13} \mathrm{C}_{\text {org }}$ records}

The TOC and TN records show distinct temporal variations throughout the analyzed interval. The TOC value
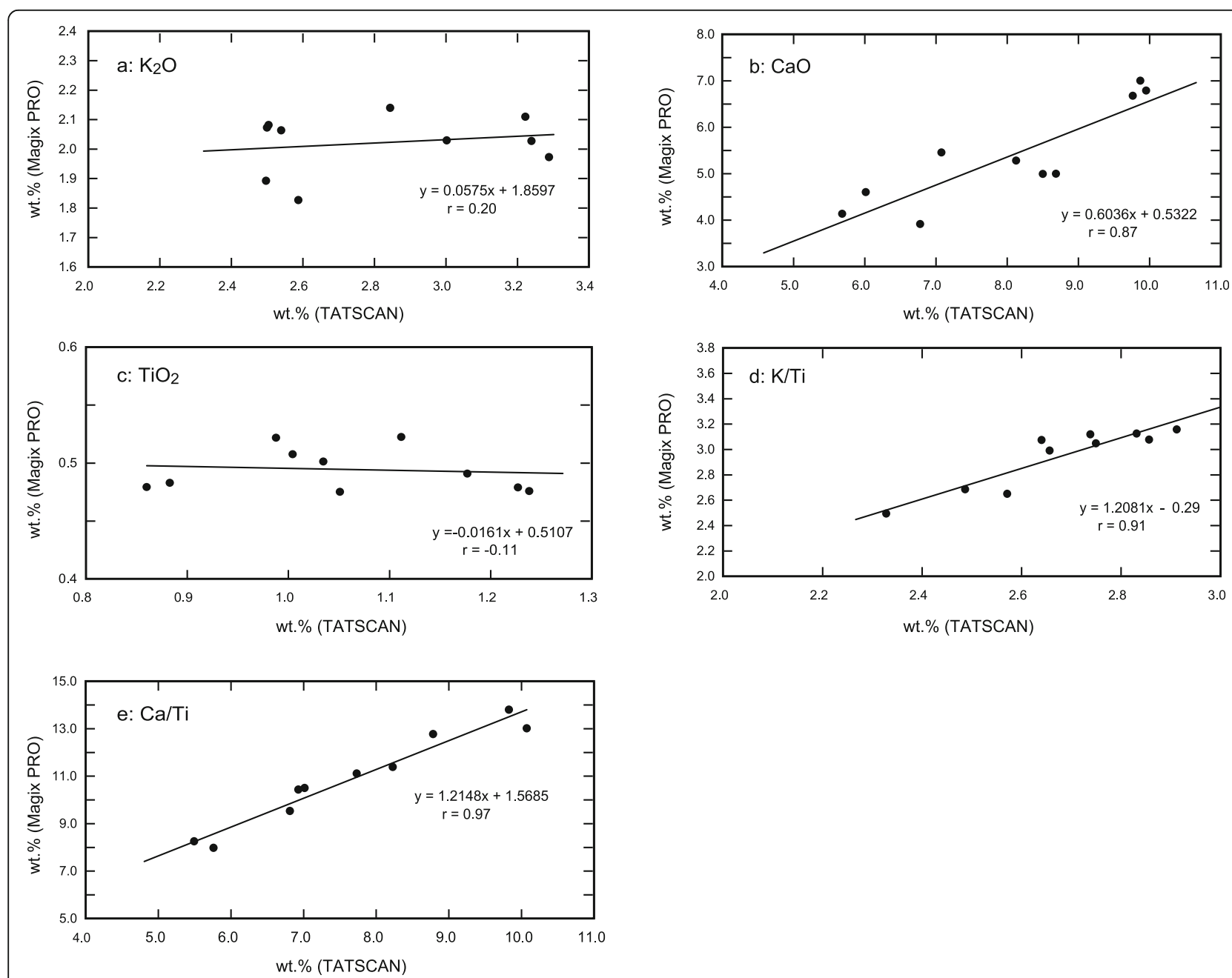

Fig. 5 The relationships between the major element abundances between TATSCAN-F2 and Magix PRO analyses for important proxies discussed in this paper 


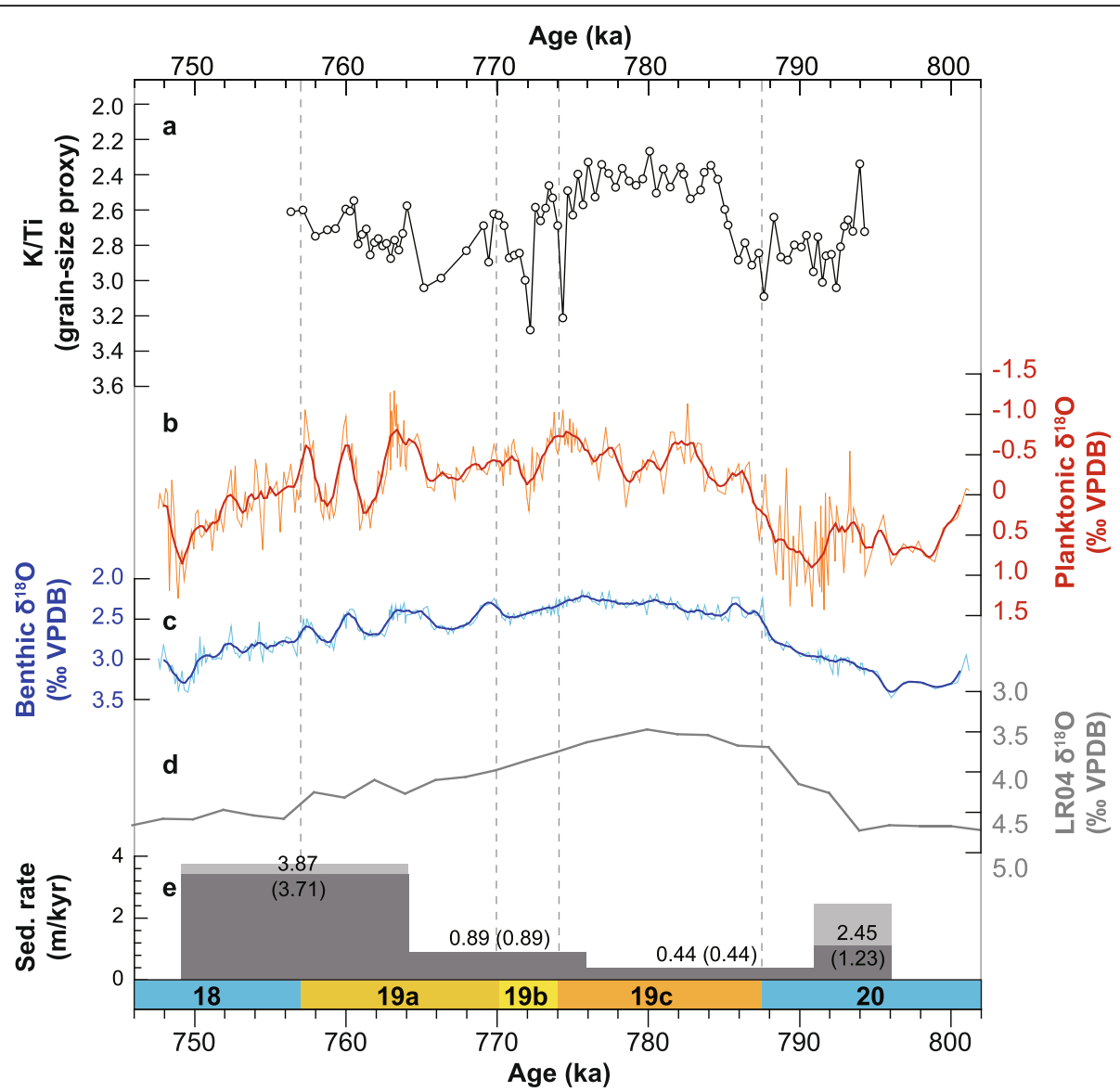

Fig. 6 Temporal changes in sedimentological parameters from MIS 20 to MIS 18 at the CbCS. a KTi record obtained by TATSCAN-F2, which is interpreted as a grain-size proxy (see details in the text). Note the smaller $\mathrm{K} / \mathrm{Ti}$ value indicates coarser sediment. $\mathbf{b}$ High-resolution $\delta^{18} \mathrm{O}$ records from planktonic (Globigerina bulloides) and $\mathbf{c}$ benthic foraminifers at the CbCS (Haneda et al. 2020b). Thick lines are 1000 yr moving average profiles. d The LR04 benthic stack (Lisiecki and Raymo 2005). e Calculated sedimentation rate variation at the CbCS (after Suganuma et al. 2018) with (light gray bars) and without (dark gray bars) sandstone beds. Detailed information on the age model is given in Suganuma et al. (2018). Dashed lines are Marine Isotope Stage and substage boundaries, based on Haneda et al. (2020b)

remained relatively constant at $\sim 0.4-0.5 \mathrm{wt} \%$ from 795 to $780 \mathrm{ka}$ but generally increased to $\sim 0.65 \mathrm{wt} \%$ from 780 to 770 ka with some variation (Fig. 7). Subsequently, it decreased gradually from 770 to $755 \mathrm{ka}$, with the exception at $\sim 764$ and $\sim 760 \mathrm{ka}$. The TN content from 795 to $790 \mathrm{ka}$ was $~ 0.04-0.05 \mathrm{wt} \%$ with minor variation, and gradually increased to $\sim 0.08 \mathrm{wt} \%$ from 790 to 770 ka. From 770 to $755 \mathrm{ka}$, it was generally 0.04-0.06 wt\% with the exception at $\sim 764$ and $\sim 760 \mathrm{ka}$. Relatively large variations in the form of at least two maxima, at 764 and $\sim 760 \mathrm{ka}$, were observed in the cases of TOC and TN (Fig. 7). Overall, the TOC and TN contents generally increased during MIS 19; however, the exact timings of these increases are not synchronous, resulting in a pronounced temporal variation in the $\mathrm{C} / \mathrm{N}$ ratio.

Throughout the analyzed interval, the $\mathrm{C} / \mathrm{N}$ ratio record changes in association with glacial-interglacial cycles from the late MIS 20 to the early MIS 18. In other words, the value of the $\mathrm{C} / \mathrm{N}$ ratio from 795 to $790 \mathrm{ka}$
(MIS 20) and from 770 to $755 \mathrm{ka}$ (late MIS 19 to early MIS 18), corresponding to glacial periods, was generally higher $(\sim 7$ to $\sim 11)$ than that from 790 to $770 \mathrm{ka}$ (late MIS 20 to early MIS 19 corresponding to deglacial to interglacial periods when the $\mathrm{C} / \mathrm{N}$ ratio $=\sim 5.5$ to $\sim 9.5$ ) (Fig. 7). However, the ratio showed relatively large millennial to multimillennial-scale variations especially during 795 to $790 \mathrm{ka}$ and 765 to $755 \mathrm{ka}$ within early glacial periods (Fig. 7).

The $\delta^{13} C_{\text {org }}$ record generally showed a similar trend as that for the $\mathrm{C} / \mathrm{N}$ ratio; this was also indicative of the glacial-interglacial cycles from the late MIS 20 to the early MIS 18 , having relatively large variations especially during 795 to $790 \mathrm{ka}$ and 765 to $755 \mathrm{ka}$. The $\delta^{13} \mathrm{C}_{\text {org }}$ values from 795 to $790 \mathrm{ka}$ (MIS 20) and from 770 to $755 \mathrm{ka}$ (late MIS 19 to early MIS 18) corresponding to glacial periods generally ranged from $\sim-23.0$ to $-24.5 \%$, whereas they are $\sim-21.5$ to $-23.0 \%$ from 790 to 770 ka (late MIS 20 to early MIS 19) corresponding to 


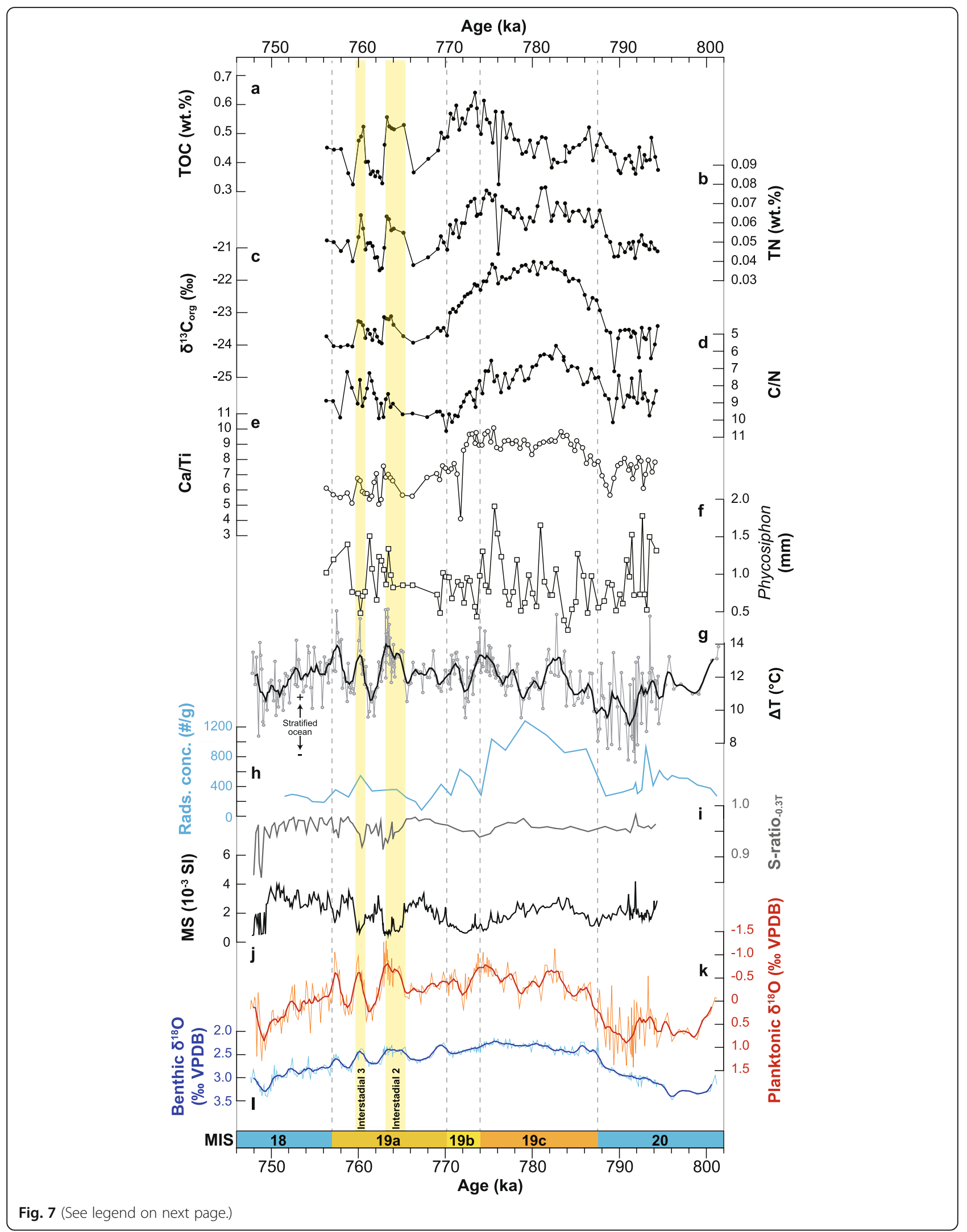


(See figure on previous page.)

Fig. 7 Temporal change in paleoceanographic parameters from MIS 20 to MIS 18 from CbCS. a Total organic carbon (TOC) record. b Total nitrogen (TN) record. $\mathbf{c}$ Carbon isotope ratio of organic carbon $\left(\delta^{13} \mathrm{C}_{\text {org }}\right)$ record. $\mathbf{d} \mathrm{C} / \mathrm{N}$ record. e $\mathrm{Ca} / \mathrm{Ti}$ record obtained by TATSCAN-F2. $\mathbf{f}$ Maximum diameter of the core of Phycosiphon. $\mathbf{g}$ The difference in water temperature between surface and bottom water $(\Delta \mathrm{T})$ from Haneda et al. (2020b). Thick lines are 1000 yr moving average profiles. h Radiolarian concentrations (Suganuma et al. 2018). i S-ratio-0.3T record (Haneda et al. 2020a). j Magnetic susceptibility record (Haneda et al. 2020a). k High-resolution $\delta^{18} \mathrm{O}$ records from planktonic (G. bulloides) and I benthic foraminifers from CbCS (Haneda et al. 2020b). Thick lines are $1000 \mathrm{yr}$ moving average profiles. Dashed lines are marine isotope stage and substage boundaries, based on Haneda et al. (2020b). Yellow shades at 764 and 760 ka highlight Millennial Isotopic Oscillation (MIO)-Interstadial 2 and MIO-Interstadial 3, respectively (Haneda et al. 2020b), which correspond to relatively large variations in TOC and TN values. Although Sratio-0.3T, magnetic susceptibility, and $\delta^{18} \mathrm{O}$ records of the $\mathrm{CbCS}$ has been the subject of a series of investigations over the past 5 years (Suganuma et al. 2015, 2018; Okada et al. 2017; Simon et al. 2019; Haneda et al. 2020a, b) during which successive refinements have been incorporated, this paper refers to the latest and refined data set of Haneda et al. (2020a, b)

deglacial to interglacial periods (Fig. 7). Similar to the temporal change in the $\mathrm{C} / \mathrm{N}$ ratio, there may be millennial to multimillennial-scale changes in the $\delta^{13} \mathrm{C}_{\text {org }}$ values, although the amplitudes of such shorter-scale changes are low (Fig. 7).

The obtained results are also listed in Table S2 (see Additional files).

\subsection{Dry bulk density}

Dry bulk density of the $\mathrm{CbCS}$ sediments ranges from 1.34 to $1.73 \mathrm{~g} / \mathrm{cm}^{3}$ (Table S3 in Additional files). Among the analyzed samples (83 samples), approximately $90 \%$ of the samples (75 samples) show a dry bulk density value ranging from 1.45 to $1.60 \mathrm{~g} / \mathrm{cm}^{3}$.

As for the temporal trend, the values of the dry bulk density during MIS 19c are generally lower than those in other periods (Table S3 in Additional files). This feature may partly be due to the difference in lithology. In particular, the lithology especially during MIS 19c is siltstone-dominated and is also characterized with the less presence of sand layers (Fig. 3).

\subsection{Trace fossil records}

Several ichnogenera were recognized in the surface of the paleomagnetic cores, including Chondrites, Phycosiphon, and the burrows of indeterminate ichnogenus. Among them, Phycosiphon is the most abundant ichnogenus (Fig. 4), and thus the maximum diameter of this ichnogenus was measured (see Section 3.4). As mentioned earlier, it is commonly interpreted that the burrow diameter reflects the body diameter of the tracemaker; thus, the maximum burrow diameter represents biological parameter of the trace-maker, which is linked with relative oxygen levels (Boyer and Droser 2011 and references therein).

The obtained dataset is summarized in Table S4 (see Additional files). As a result of our observation, the maximum diameter of the core of Phycosiphon observed in the surface of each paleomagnetic core ranges from 0.254 to $1.905 \mathrm{~mm}$ (Table S4). As for the temporal trend, the maximum diameter of Phycosiphon does not change in association with glacial-interglacial cycles from the late MIS 20 to the early MIS 18, unlike the temporal trends of the $\mathrm{C} / \mathrm{N}$ ratio and $\delta^{13} \mathrm{C}_{\text {org }}$ records that are described in the previous section (Fig. 7). Rather, the diameter of the core of Phycosiphon varied largely without any distinct long-term trend throughout the analyzed interval (Fig. 7).

\section{Discussion}

5.1 Variations in grain size as inferred from the $\mathrm{K} / \mathrm{Ti}$ ratio

For the interpretation of the high-resolution temporal change in grain size, it is useful to evaluate a proxy for the grain size as well as physical grain-size analysis. In particular, the $\mathrm{K} / \mathrm{Ti}$ ratio is used as the grain-size proxy in this study. On the one hand, relative changes in $\mathrm{Ti}$ abundance have been used previously as grain-size proxies owing to the expected enrichment of this element in silty to sandy sediment relative to its abundance in clay minerals (despite the presence of clay-bound $\mathrm{Ti}$, for example) (Calvert and Pedersen 2007). On the other hand, $\mathrm{K}$ is most strongly associated with aluminosilicates such as clay minerals (Calvert and Pedersen 2007). Therefore, the elemental ratio of coarse grain-enriched element $(\mathrm{Ti})$ relative to clay-enriched element $(\mathrm{K})$ can be used as a grain-size proxy. In fact, the K/Ti ratio has been used as a proxy for the grain size of clastic material in various studies (e.g., Kemp and Izumi 2014; Xie et al. 2014; Yang et al. 2015).

As for the temporal trend, the K/Ti ratio from 794 to $792 \mathrm{ka}$ (MIS 20) shows an increasing trend, which is suggestive of a fining trend (Fig. 6). Subsequently, the ratios from 792 to 786 ka (late MIS 20 to early MIS 19c) are essentially constant, although there are slight variations (Fig. 6). The K/Ti ratio from 786 to $784 \mathrm{ka}$ (MIS 19c) shows a decreasing trend (= coarsening trend), and then the ratio keeps constant from 784 to $772 \mathrm{ka}$ (MIS $19 \mathrm{c}$ to early MIS 19b), although there are two distinct peaks at $\sim 774$ and $772 \mathrm{ka} \mathrm{(Fig.} \mathrm{6).} \mathrm{The} \mathrm{K/Ti} \mathrm{ratio} \mathrm{after}$ $772 \mathrm{ka}$ (late MIS 19b to MIS 19a) shows large change patterns (i.e., multimillennial-scale changes), which are concordant with the temporal trends in the $\delta^{18} \mathrm{O}$ records of the benthic, subsurface, and surface planktonic foraminifers (Haneda et al. 2020b) (Fig. 6). As is discussed in 
later section (see Section 5.4), the peaks in $\delta^{18} \mathrm{O}$ records during MIS 19a reflect the northward displacement of Kuroshio Extension Front (Haneda et al. 2020b). The northward displacements of Kuroshio Extension Front during MIS 19a may have been coincident with the decreases in the $\mathrm{K} / \mathrm{Ti}$ ratio (i.e., coarsening trends). In particular, based on the sedimentological study using the Holocene marine core samples collected from the continental slope setting (water depths: 449-1728 m), off the Boso Peninsula, the intensification of the Kuroshio influence may result in the coarsening of the grain size because finer grains are easily transported when the Kuroshio Current is intensified (Ajioka et al. 2019). However, to further evaluate the mechanism of the likely multimillennial-scale changes in the grain size of clastic material, high-resolution grain-size analysis with the pretreatments of the removal of organic matter, opal, and biogenic carbonate is required in the future.

5.2 Source and mass accumulation rate of organic carbon In general, the $\mathrm{C} / \mathrm{N}$ ratio of marine sediments varies depending on the source of the organic matter. The $\mathrm{C} / \mathrm{N}$ ratio is high (typically $>10$ ) in the case of terrestrial plants and low (<10) for marine plankton/algae (Meyers 1994). Thus, the $\mathrm{C} / \mathrm{N}$ ratio is used as a proxy for organic matter source. However, the TN values occasionally include inorganic nitrogen absorbed in clay minerals. Therefore, it is necessary to cross-check with the other proxies to more precisely evaluate the source of the organic matter in marine sediments. The $\delta^{13} \mathrm{C}_{\text {org }}$ value of marine sediments can also be used as a proxy for organic matter source. The $\delta^{13} C_{\text {org }}$ value of terrestrial C3 plants is generally $-27 \%$, whereas that of marine plankton ranges from -22 to $-18 \%$ (Fry and Sherr 1984). The scatter plot of the $\delta^{13} C_{\text {org }}$ versus the $\mathrm{C} / \mathrm{N}$ values shows a moderate negative correlation $(r=-$ 0.67; Fig. 8). However, considering that the correlation coefficient is -0.67 , it is suggested that, in the case of this study, the influence of the inorganic nitrogen is not negligible. Therefore, to interpret the source of organic matter (especially organic carbon), it is better to use the $\delta^{13} C_{\text {org }}$ values.

Based on the results of the $\delta^{13} \mathrm{C}_{\text {org }}$ measurements, it is interpreted that the organic carbon of the $\mathrm{CbCS}$ sediments was mostly composed of marine plankton during MIS 19c and 19b, whereas that during MIS 20, 19a and 18 was characterized by a mixture of both marine plankton and terrigenous organic carbon (Fig. 7). To further interpret this quantitatively, we estimated the contributions of marine plankton organic carbon and terrestrial organic carbon by using a two-end-member isotope mixing model (cf. Belicka and Harvey 2009), assuming that the end member values of marine and terrestrial organic matter are $\delta^{13} C_{\text {org }}=-21$ and $-27 \%$, respectively (see Table S2 in Additional files). As a result, the contributions of marine organic carbon during MIS 19c and 19b are approximately estimated as from 70 to $90 \%$, whereas those during MIS 20, 19a and 18 were generally lower than 60\% (see Table S2 in Additional Files).

As for the temporal changes in the source and amount of organic carbon, it is interpreted that the input of marine and terrestrial organic carbon and their balance control the contribution of marine organic carbon versus terrestrial organic carbon within the sediments. To

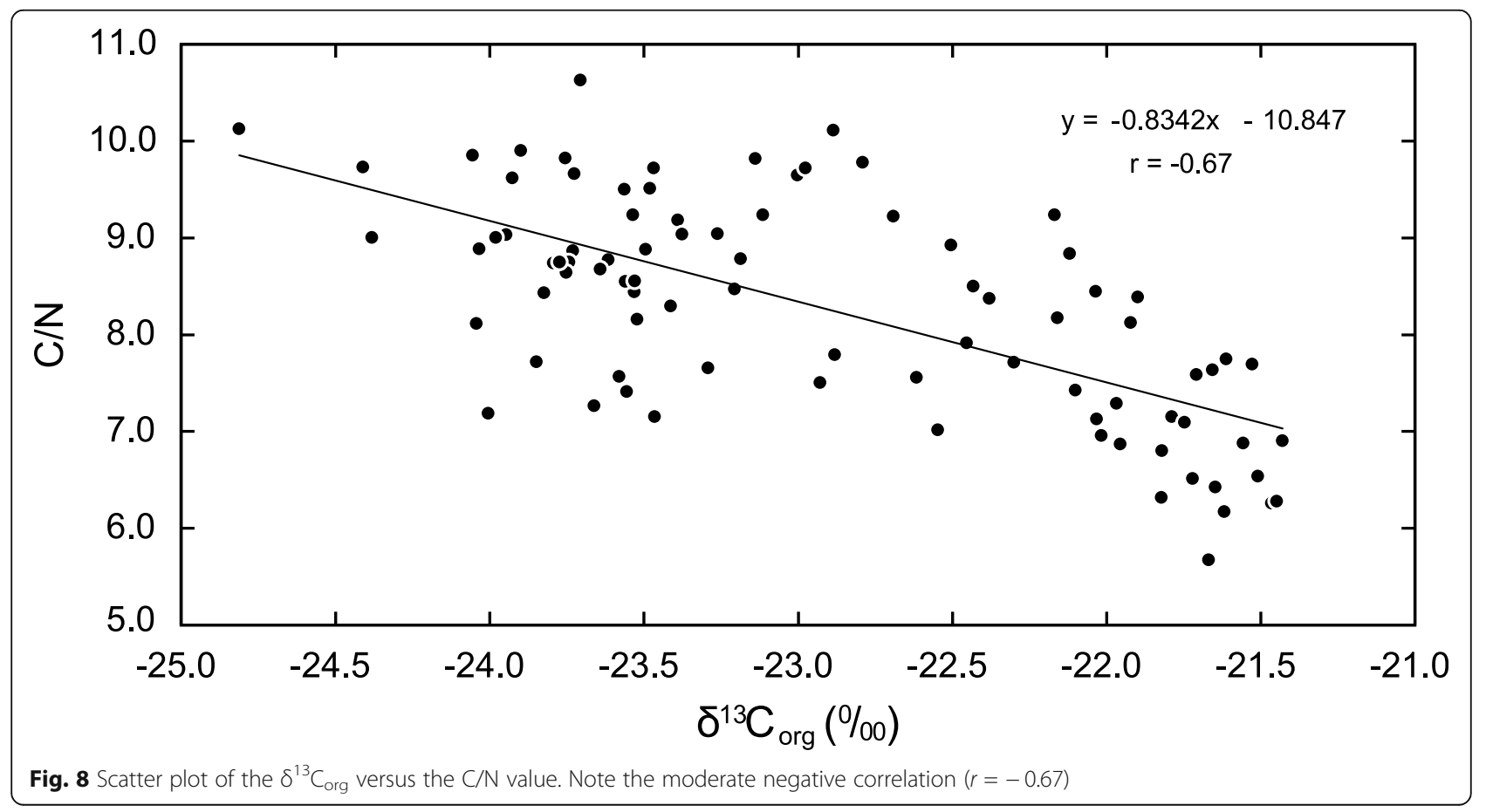




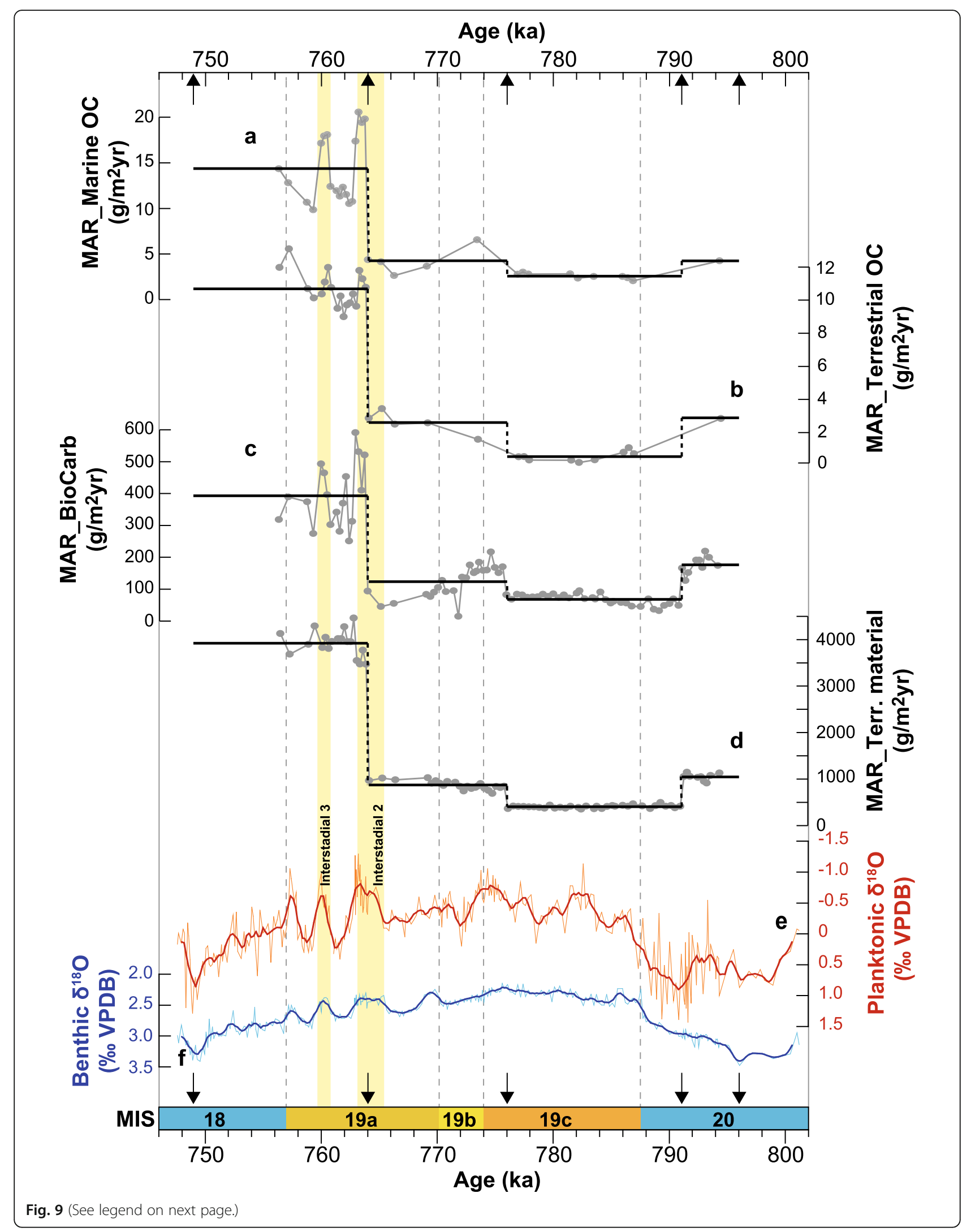


(See figure on previous page.)

Fig. 9 Mass accumulation rates (MARs) of some selected materials. a Calculated MAR of marine organic carbon. Gray plots are calculation for individual samples, and black bold lines indicate the average values of the interval between two age controlling points. $\mathbf{b}$ Calculated MAR of terrestrial organic carbon. Gray plots are calculation for individual samples, and black bold lines indicate the average values of the interval between two age controlling points. c Calculated MAR of biogenic carbonate. Gray plots are calculation for individual samples, and black bold lines indicate the average values of the interval between two age controlling points. $\mathbf{d}$ Calculated MAR of terrigenous material. Gray plots are calculation for individual samples, and black bold lines indicate the average values of the interval between two age controlling points. e Highresolution $\delta^{18} \mathrm{O}$ records from planktonic (G. bulloides) and $\mathbf{f}$ benthic foraminifers from CbCS (Haneda et al. 2020b). Thick lines are $1000 \mathrm{yr}$ moving average profiles. Dashed lines are Marine Isotope Stage and substage boundaries, based on Haneda et al. (2020b). Yellow shades at $\sim 764$ and 760 ka highlight Millennial Isotopic Oscillation (MIO)-Interstadial 2 and MIO-Interstadial 3, respectively (Haneda et al. 2020b), which correspond with relatively large variations in TOC and TN values. Black arrows indicate the age controlling points (cf. Suganuma

et al. 2018, Haneda et al. 2020b)

further discuss this issue quantitatively, we calculated the mass accumulation rate (MAR) of both marine and terrestrial organic carbon by using the data on organic carbon, sedimentation rate, and dry bulk density. For the details on the MAR calculation, see Table S2 (see Additional files). The MARs of marine and terrestrial organic carbon and their temporal changes are illustrated in Fig. 9. Because of the large variations in the sedimentation rate (Fig. 6), the MARs of marine and terrestrial organic carbon throughout the studied interval varied considerably (Fig. 9). In particular, during MIS 19c, the MARs of both marine and terrestrial organic carbon were extremely low (Fig. 9), due to the low sedimentation rate. The MAR of marine organic carbon during late MIS 19a ranges from $\sim 10$ to $20 \mathrm{~g} / \mathrm{m}^{2}$ year (average $=14.4 \mathrm{~g} / \mathrm{m}^{2}$ year; see Table S2), whereas that from late MIS 20 to MIS 19c ranges from $\sim 2$ to $3 \mathrm{~g} / \mathrm{m}^{2}$ year (average $=2.6$ $\mathrm{g} / \mathrm{m}^{2}$ year; see Table S2) (Fig. 9). The MAR of terrestrial organic carbon during late MIS 19a ranges from $\sim 9$ to $13 \mathrm{~g} / \mathrm{m}^{2}$ year (average $=10.7 \mathrm{~g} / \mathrm{m}^{2}$ year; see Table S2), whereas that from late MIS 20 to MIS 19c ranges from $\sim 0.2$ to $1 \mathrm{~g} / \mathrm{m}^{2}$ year (average $=0.5 \mathrm{~g} / \mathrm{m}^{2}$ year; see Table S2) (Fig. 9). These results mean that the MAR of terrestrial organic carbon during late MIS 19a was $~ 20$ times higher relative to that from late MIS 20 to MIS 19c, while the MAR of marine organic carbon during late MIS 19a was only $\sim 5.5$ times higher relative to that from late MIS 20 to MIS 19c (Fig. 9). Taken together, the results of the MAR calculation are indicative of the characteristics of the temporal change in the organic carbon source; specifically, the contribution of marine organic carbon relative to terrestrial organic carbon significantly increased during MIS 19c (Fig. 9).

\subsection{Biogenic carbonate and terrigenous material}

The $\mathrm{Ca} / \mathrm{Ti}$ ratio, which reflects biogenic carbonate content, tends to be higher especially during MIS 19c (Fig. 7). It is occasionally interpreted that the $\mathrm{Ca} / \mathrm{Ti}$ ratio generally reflects biogenic productivity (e.g., Riethdorf et al. 2013; Hyodo et al. 2017). The radiolarian (i.e., secondary producer) concentration was also higher especially during MIS 19c (Suganuma et al. 2018; Fig. 7). Furthermore, based on the observation of the TB2 core that was collected at a site ca. $200 \mathrm{~m}$ east of the Chiba section, the temporal trend in the diatom (i.e., primary producer) concentration is highly similar with that in the radiolarian, showing that the diatom concentration was higher especially during MIS 19c (Tanaka et al. 2017).

However, it is not reasonable to consider that the temporal variations in $\mathrm{Ca} / \mathrm{Ti}$ ratio and siliceous microfossil abundances (radiolarian and diatom concentrations) of the sediments directly reflect the past biogenic productivity in the case of this study, because the sedimentation rate was lower especially during the earlier part of MIS 19 (Fig. 6). Therefore, it is also possible that the temporal changes in the $\mathrm{Ca} / \mathrm{Ti}$ ratio and radiolarian concentrations were controlled by of the changes in the terrigenous input rate.

To further discuss this issue quantitatively, the MARs of both biogenic carbonate and terrigenous material were calculated using the data from the XRF analysis, sedimentation rate, and dry bulk density (see Table S1 for detailed methods of calculation). The assumption of MAR calculation, in particular, the equations for calculating the percentages of biogenic carbonate and terrigenous material of the sediments are based on Kido et al. (2007). The detailed steps and assumptions on the MAR calculation have also been described in Table S1 (see Additional files).

The results are shown in Fig. 9. Because of the large variations in sedimentation rate (Fig. 6), the MARs of biogenic carbonate and terrigenous material throughout the studied interval varied considerably (Fig. 9; see Table S1 for detailed methods of calculation). The MAR of biogenic carbonate during late MIS 19a ranges from 250 to $600 \mathrm{~g} / \mathrm{m}^{2}$ year (average $=393.0 \mathrm{~g} / \mathrm{m}^{2}$ year; see Table S1), whereas that from late MIS 20 to MIS 19c ranges from $\sim 30$ to $95 \mathrm{~g} / \mathrm{m}^{2}$ year (average $=68.1 \mathrm{~g} / \mathrm{m}^{2}$ year; see Table S1) (Fig. 9). For the terrigenous material, its MAR during late MIS 19a ranges from $\sim 3500$ to $4500 \mathrm{~g} / \mathrm{m}^{2}$ year (average $=3921.7 \mathrm{~g} / \mathrm{m}^{2}$ year; see Table S1), whereas that from late MIS 20 to MIS 19c ranges from $\sim 350$ to $500 \mathrm{~g} / \mathrm{m}^{2}$ year (average $=405.9 \mathrm{~g} / \mathrm{m}^{2}$ year; see Table S1) (Fig. 9). Such results mean that the MAR 
of terrigenous material during late MIS 19a was $\sim 10$ times higher relative to that from late MIS 20 to MIS 19c, while the MAR of biogenic carbonate during late MIS 19a was only $\sim 6$ times higher relative to that from late MIS 20 to MIS 19c (Fig. 9). Overall, it is concluded that the increase in the $\mathrm{Ca} / \mathrm{Ti}$ ratio (= the proxy for biogenic carbonate) during MIS 19c (Fig. 7) was not caused by the increase in the MAR of biogenic carbonate that actually decreased during the interval. Instead, the increase in the $\mathrm{Ca}$ /Ti ratio during MIS 19 c was due to the significant decrease in the MAR of terrigenous material that exceeded the decrease in the MAR of biogenic carbonate during MIS 19c.

\subsection{Multimillennial-scale variability in geochemical proxies during MIS 19a}

Another important aspect of our dataset is the relatively large variations in the TOC and TN values during MIS 19a. In particular, at least two maxima can be observed in the TOC and TN values, at $\sim 764$ and $\sim 760 \mathrm{ka}$, respectively (Fig. 7). The variation amplitude of the TOC values during the analyzed interval is $0.32 \mathrm{wt} \%(0.32-$ 0.64 wt\%), whereas the amplitudes of the peaks at 764 and $760 \mathrm{ka}$ are $\sim 0.23(\sim 71.9 \%$ of the whole range $)$ and $\sim 0.20$ wt\% $(\sim 62.5 \%$ of the whole range $)$, respectively. Similarly, for the TN values, the amplitudes of the peaks at 764 and $760 \mathrm{ka}$ are $\sim 0.027(\sim 62.8 \%$ of the whole range) and $\sim 0.024 \mathrm{wt} \%(\sim 55.8 \%$ of the whole range $)$, respectively.

The factors that are important to control organic matter content in marine sediments are sediment surface area, sedimentation rate, and preservation efficiency (e.g., Burdige 2006). In general, sediment-specific surface area controls the amount of organic matter in sediments, and finer-grained sediments (especially clay minerals) have a larger surface area (Keil and Hedges 1993; Kennedy et al. 2002). However, the temporal trend in the K/ $\mathrm{Ti}$ ratio (= proxy for grain size; also see Section 5.1), which shows relatively small values at both $\sim 764$ and $\sim$ 760 ka (Fig. 6), suggests that the sediments at $\sim 764$ and $\sim 760$ ka are relatively coarse. Regarding sedimentation rate, higher sedimentation rate prevents the degradation of organic matter by reducing the oxygen exposure time (e.g., Hartnett et al. 1998). However, because the sedimentation rate of the $\mathrm{CbCS}$ has been based only on a few age controlling points (Suganuma et al. 2018), it is not possible to discuss the actual effect of sedimentation rate on the changes in organic matter content of the $\mathrm{CbCS}$ sediments on millennial to multimillennial timescale.

Alternatively, as mentioned earlier, because the amount of organic matter in marine sediments is also controlled by the preservation efficiency (Burdige 2006), it is possible that preservation efficiency of organic matter was higher at 764 and $760 \mathrm{ka}$. In general, the organic carbon content in marine sediments in either high-productivity (thus high organic-carbon flux) regions or under low-oxygen bottom waters is relatively high (Hedges 2002; Burdige 2006). In the case of the $\mathrm{CbCS}$, it is likely that both the organic-carbon flux and the bottom-water oxygen level affected the organic matter content at 764 and $760 \mathrm{ka}$ (see the later discussion and Fig. 9).

Especially in terms of the bottom-water oxygen level, there are several evidences suggesting that the bottomwater oxygen level lowered at $\sim 764$ and $\sim 760 \mathrm{ka}$. First, this interpretation is consistent with the lower S-ratio and magnetic susceptibility in the same intervals (Okada et al. 2017; Simon et al. 2019; Haneda et al. 2020a) (Fig. 7). Because remarkable decreases in S-ratio and magnetic susceptibility tend to be accompanied by the dissolution of magnetite grains (e.g., Suganuma et al. 2008), the reductive condition would have occurred at 764 and $760 \mathrm{ka}$. Another supporting evidence is the trace-fossil data. During MIS 19a, the distinct decrease in the diameter of the core of Phycosiphon occurred at $760 \mathrm{ka}$ (Fig. 7). Although the decrease in the maximum diameter of Phycosiphon at around 764 ka is less clear because of the low temporal-resolution data especially during 770 to $765 \mathrm{ka}, 764 \mathrm{ka}$ corresponds with the interval dominated by the smaller Phycosiphon (Fig. 7). In the case of deepmarine sediments characterized with a sedimentation rate greater than $2 \mathrm{~cm} / \mathrm{kyr}$ and with the organic-carbon content greater than $0.1 \mathrm{wt} . \%$, the most significant controlling factor of the burrow size is the bottom-water oxygen content (e.g., Wetzel and Uchman 2012). In particular, the lower the bottom-water oxygen level is, the smaller the burrow size is (Wetzel and Uchman 2012). Therefore, our Phycosiphon records also support the interpretation that the bottom-water oxygen level lowered at 764 and $760 \mathrm{ka}$. With respect to the bottom-water redox conditions of the CbCS, Hyodo et al. (2017) suggested that a persistent anoxic depositional environment existed and intercalated with short-term oxic events. However, the siltstones of the CbCS are highly bioturbated, and large $(>1 \mathrm{~cm})$ trace fossils produced by marine invertebrates are often observed in the CbCS sediments (Nishida et al. 2016). These sedimentary characteristics are indicative of dysoxic (dissolved oxygen $=0.2-2.0 \mathrm{ml} /$ l) to oxic (dissolved oxygen $=2.0-8.0 \mathrm{ml} / \mathrm{l}$ ) conditions instead of an anoxic (dissolved oxygen $=0 \mathrm{ml} / \mathrm{l}$ ) bottomwater condition (cf. see Tyson and Pearson 1991 for the classification of redox conditions). As for the modern Pacific off Boso Peninsula (water depth ranging from 0 to $1500 \mathrm{~m}$ ), dissolved oxygen values range from $\sim 1.5$ to $4.5 \mathrm{ml} / \mathrm{l}$ (Yang et al. 1993), suggesting that our new interpretation on the redox conditions (dysoxic to oxic) is more plausible. 
In addition, our interpretation that the bottom water oxygen content lowered at $\sim 764$ and $\sim 760 \mathrm{ka}$ is also consistent with the available paleoceanographic proxies from the $\mathrm{CbCS}$. The latest high-resolution (centurialresolution) analysis of the $\delta^{18} \mathrm{O}$ records of the benthic, subsurface, and surface planktonic foraminifers from the $\mathrm{CbCS}$ suggests multiple millennial isotopic oscillations (MIOs), which are composed of the MIO-Stadial 1 to the MIO-Stadial 4 and the MIO-Interstadial 1 to the MIO-Interstadial 4 during MIS 19 (Haneda et al. 2020b). The increases in the organic-matter content at 764 and $760 \mathrm{ka}$ observed in this study (Fig. 7) correspond to the MIO-Interstadial 2 and 3, respectively. During these MIO Interstadials, the difference in the water temperature between surface and bottom water $(\Delta \mathrm{T})$ also fluctuated (Fig. 7); in particular, a decrease in the $\delta^{18} \mathrm{O}$ value of the surface water and increase in the $\Delta \mathrm{T}$ represent an increase in the sea surface temperature (SST) and increased stratification owing to the northward displacement of the Kuroshio Extension Front (for more detailed information, see Haneda et al. 2020b).

Based on the discussion above, we propose the hypothesis that the two peaks in the TOC and TN values at 764 and 760 ka were caused by enhanced organicmatter preservation due to relative decrease in the bottom-water oxygen level, which were partly attributable to increased ocean stratifications at 764 and $760 \mathrm{ka}$ because of the northward displacement of the Kuroshio Extension Front. However, the above hypothesis has not been fully tested, because the interpretation based on the proxies we employed are not unique and there are rooms for other interpretations. For example, increased surface productivity or decreased terrigenous input at 764 and $760 \mathrm{ka}$ may be other causes for higher organic carbon content. In fact, based on our data, it is not certain whether the increases in organic-carbon content at $\sim 764$ and 760 ka were due to the synchronous increase in biogenic productivity in surface water, as mentioned earlier. If the ocean stratification occurred at 764 and $760 \mathrm{ka}$ due to the northward displacement of the Kuroshio Extension Front, it may not have caused the increase in biogenic productivity because the Kuroshio water is oligotrophic due to low biogenic productivity in the downwelling-dominant subtropical gyre. Regardless, to verify the hypothesis, further studies should prioritize the reconstruction of the variation in both the bottomwater oxygen level and the biogenic productivity by high-resolution analysis of multiple proxies. Then, analyses of various proxies for paleo-ocean redox conditions, such as pyrite framboids and redox-sensitive trace elements (e.g., Wilkin et al. 1996; Algeo and Maynard 2004), and proxies for paleo-ocean productivity, such as Barium concentrations (Dymond et al. 1992), are important for subsequent studies.

\section{Conclusions}

In this study, we performed multiproxy sedimentological and geochemical analyses of the Chiba composite section (CbCS), including the Chiba section, to establish its highresolution chemostratigraphy and reconstruct its paleoenvironments in detail. Although the temporal trends in the $\mathrm{K} / \mathrm{Ti}$ ratio (= a proxy for grain size of clastic material) varied largely throughout the analyzed interval and thus are not clearly indicative of glacial-interglacial changes, the K/ Ti profile during MIS 19a shows variation pattern similar to multimillennial-scale variations in $\delta^{18} \mathrm{O}$ records. The $\mathrm{C} /$ $\mathrm{N}$ ratio and carbon isotope ratio of organic carbon $\left(\delta^{13} \mathrm{C}_{\mathrm{org}}\right)$ records of the $\mathrm{CbCS}$ sediments indicate that the sedimentary organic matter was mostly composed of marine organic matter especially during the interglacial maximum (MIS 19c). However, during glacial periods (MIS 18, 19a, and 20 ), the organic matter was characterized by a mixture of both marine and terrigenous organic matter. Furthermore, mass accumulation rates (MARs) of organic carbon, biogenic carbonate, and terrigenous material were calculated to quantitatively interpret the paleoenvironmental changes. MAR calculations supported the interpretation that the contribution of marine organic carbon relative to terrestrial organic carbon increased during MIS 19c, and that the contribution of the terrigenous material relative to biogenic carbonate decreased during MIS 19c. In addition, although temporal records of the total organic carbon (TOC) and total nitrogen (TN) were in association with glacial-interglacial cycles, relatively large variations in TOC and TN values were observed especially during MIS 19a. It is plausible that these variations can be ascribed to the change in bottom-water oxygen levels, based on the interpretation of our trace-fossil data, although it is not certain whether the increases in organic-carbon flux at $\sim 764$ and $760 \mathrm{ka}$ were due to the synchronous increases in biogenic productivity in surface water. The relative decrease in bottom-water oxygen level was probably due to the increased ocean stratification because of the northward displacement of the Kuroshio Extension Front.

\section{Supplementary Information}

The online version contains supplementary material available at https://doi. org/10.1186/s40645-020-00393-5

Additional file 1: Table S1. Full dataset for XRF analysis by TATSCANF2 and Magix PRO, with detailed descriptions of the MAR calculation.

Additional file 2: Table S2. Full dataset for organic carbon and nitrogen analysis, with detailed descriptions of the MAR calculation.

Additional file 3: Table S3. Full dataset for the analysis of dry bulk density.

Additional file 4: Table S4. Full dataset for trace-fossil analysis.

Abbreviations

CbCS: Chiba composite section; GSSP: Global Boundary Stratotype Section and Point; M-B boundary: Matuyama-Brunhes paleomagnetic polarity boundary; MAR: Mass accumulation rate; MIO: Millennial Isotopic Oscillation; 
MIS: Marine Isotope Stage; TN: Total nitrogen; TOC: Total organic carbon; $\delta^{13} \mathrm{C}_{\text {org }}$ : Carbon isotope ratio of organic carbon

\section{Acknowledgements}

We thank all those who involved in this research project (for the full list of members, see the GSSP proposal group 2019). We also greatly appreciate the support provided by Ichihara City, Chiba Prefecture, and the Ministry of Education. We thank Editage (www.editage.com) for English language editing. We conducted a part of this study through a joint-use system at the Center for Advanced Marine Core Research, Kochi University (Grants 16A023/ 16B021). Our manuscript was greatly improved by the constructive comments from the editor and reviewers.

\section{Authors' contributions}

$\mathrm{Kl}$ performed the TOC, TN, and $\delta^{13} \mathrm{Corg}_{\text {org }}$ measurements, observed and analyzed trace fossils, analyzed the XRF data, and wrote the main body of this manuscript. YH collected the sediment samples and helped with the data interpretation. YS collected the sediment samples and helped with the TOC, TN, and $\delta^{13} \mathrm{C}_{\text {org }}$ analyses as well as the data interpretation. MO collected the sediment samples, performed the TATSCAN analysis along with $\mathrm{TM}$, and helped with the data interpretation. YK helped with the TOC, TN, and $\delta^{13} \mathrm{C}_{\text {org }}$ measurements as well as with the data interpretation. NN greatly helped with the data interpretation. MK helped with the TOC, TN, and $\delta^{13} \mathrm{C}_{\text {org }}$ analyses. TM performed the TATSCAN-F2 and Magix PRO analyses along with MO. All authors read and approved the final manuscript.

\section{Authors' information}

$\mathrm{KI}$ is an assistant professor at Chiba University, Japan; YH is a post-doctoral fellow at the Geological Survey of Japan, AIST; YS is an associate professor at NIPR and the Graduate University for Advanced Studies (SOKENDAI), Japan; $\mathrm{MO}$ is a professor at Ibaraki University, Japan; YK is a researcher at the National Museum of Nature and Science, Japan; NN is an associate professor at Tokyo Gakugei University, Japan; MK is a doctoral student at the National Institute of Polar Research and the Graduate University for Advanced Studies (SOKENDAl); TM is a technician at the Center for Advanced Marine Core Research, Kochi University.

\section{Funding}

This work was supported by Grants-in-Aid for Scientific Research (KAKENHI) (Grant Numbers 17H06561, 16H04068, and 19H00710) from the Japan Society for the Promotion of Science (JSPS).

\section{Availability of data and materials}

The datasets supporting the conclusions of this article are available as additional files (Tables S1, S2, S3 and S4).

\section{Competing interests}

The authors declare that they have no competing interest.

\section{Author details}

${ }^{1}$ Faculty \& Graduate School of Education, Chiba University, 1-33 Yayoi-Cho, Inage-Ku, Chiba-shi, Chiba 263-8522, Japan. 'Geological Survey of Japan, AIST, 1-1-1 Central 7, Higashi, Tsukuba, Ibaraki 305-8567, Japan. ${ }^{3}$ National Institute of Polar Research, 10-3 Midori-Cho, Tachikawa, Tokyo 190-8518, Japan. ${ }^{4}$ Department of Polar Science, School of Multidisciplinary Sciences, The Graduate University for Advanced Studies (SOKENDAI), Midori-Cho 10-3, Tachikawa, Tokyo 190-8518, Japan. ${ }^{5}$ Department of Environmental Sciences, Ibaraki University, 2-2-1 Bunkyo, Mito, Ibaraki 310-8512, Japan. ${ }^{6}$ Department of Geology and Paleontology, National Museum of Nature and Science, 4-1-1 Amakubo, Tsukuba, Ibaraki 305-0005, Japan. ${ }^{7}$ Department of Environmental Sciences, Tokyo Gakugei University, 4-1-1 Nukuikita, Koganei, Tokyo 184-8501, Japan. ${ }^{8}$ Center for Advanced Marine Core Research, Kochi University, B200 Monobe, Nankoku, Kochi 783-8502, Japan.

\section{Received: 26 March 2020 Accepted: 19 November 2020}

\section{Published online: 22 January 2021}

\section{References}

Ajioka T, Nishida N, Ikehara K (2019) Sedimentological characteristics of marine core samples obtained from east off Kamogawa, Boso Peninsula, central Japan, and reconstruction of late Quaternary paleoenvironmental changes. S-
6. Seamless Geoinformation of Coastal Zone "Eastern Costal Zone of Boso Peninsula", (2): 1-31

Algeo TJ, Maynard JB (2004) Trace-element behaviour and redox facies in core shales of Upper Pennsylvanian Kansas-type cyclothems. Chem Geol 206:289-318

Bednarz M, Mcllroy D (2009) Three-dimensional reconstruction of "phycosiphoniform" burrows: Implications for identification of trace fossils in core. Palaeontol Electronica 12:13A

Belicka LL, Harvey HR (2009) The sequestration of terrestrial organic carbon in Arctic Ocean sediments: a comparison of methods and implications for regional carbon budgets. Geochim Cosmochim Acta 73:6231-6248

Boyer DL, Droser ML (2011) A combined trace- and body-fossil approach reveals high-resolution record of oxygen fluctuations in Devonian seas. Palaios 26: $500-508$

Bromley RG (1996) Trace fossils: biology, taphonomy and applications. Chapman \& Hall, London, $\mathrm{p} 361$

Brown E, Colling A, Park D, Phillips J, Rothery D, Wright J (2001) Chapter 3-Ocean Currents, Ocean Circulation, 2nd edn. Butterworth-Heinemann, Oxford, pp 37-78

Burdige DJ (2006) Geochemistry of marine Sediments. Princeton University Press, New Jersey, p 609

Calvert SE, Pedersen TF (2007) Elemental proxies for palaeoclimatic and palaeoceanographic variability in marine sediments: interpretation and application. In: Hillaire-Marcel C, Vernal AD (eds) Proxies in Late Cenozoic Paleoceanography. Elsevier, Amsterdam, pp 567-644

Clark PU, Archer D, Pollard D, Blum JD, Rial JA, Brovkin V, Mix AC, Pisias NG, Roy M (2006) The middle Pleistocene transition: characteristics, mechanisms, and implications for long-term changes in atmospheric $\mathrm{pCO}_{2}$. Quat Sci Rev 25: 3150-3184

Dymond J, Suess E, Lyle M (1992) Barium in deep-sea sediments: a geochemical proxy for paleoproductivity. Paleoceanogr Paleoclimatol 7:163-181

Ekdale AA, Lewis DW (1991) Trace fossils and paleoenvironmental control of ichnofacies in a late Quaternary gravel and loess fan delta complex, New Zealand. Palaeogeogr Palaeoclimatol Palaeoecol 81:253-279

Elderfield H, Ferretti P, Greaves M, Crowhurst S, McCave IN, Hodell D, Piotrowski AM (2012) Evolution of ocean temperature and ice volume through the midPleistocene climate transition. Science 337:704-709

Fry B, Sherr EB (1984) $\delta^{13} C$ measurements as indicators of carbon flow in marine and freshwater ecosystems. Contrib Mar Sci 27:13-47

Goldring R, Pollard JE, Taylor AM (1991) Anconichnus horizontalis: A perspective ichnofabric-forming trace fossil in post-Paleozoic offshore siliciclastic facies. Palaios 6:250-263

GSSP Proposal Group (2019) A summary of the Chiba Section, Japan: a proposal of Global Boundary Stratotype Section and Point (GSSP) for the Middle Pleistocene Subseries. Jour Geol Soc Japan 125:5-22

Haneda Y, Okada M, Kubota Y, Suganuma Y (2020b) Millennial-scale hydrographic changes in the northwestern Pacific during marine isotope stage 19: teleconnections with ice melt in the North Atlantic. Earth Planet Sci Lett 531: 115936

Haneda Y, Okada M, Suganuma Y, Kitamura T (2020a) A full sequence of the Matuyama-Brunhes geomagnetic reversal in the Chiba composite section, central Japan. Prog Earth Planet Sci 7:44

Hartnett HE, Keil RG, Hedges Jl, Devol A (1998) Influence of oxygen exposure time on organic carbon preservation in continental margin sediments. Nature 391:572-575

Head MJ, Gibbard PL (2005) Early-Middle Pleistocene transitions: an overview and recommendation for the defining boundary. In: Head MJ, Gibbard PL (eds) Early-Middle Pleistocene Transitions: the Land-ocean Evidence, Geol Soc Spec Publ, vol, vol 247, pp 1-18

Head MJ, Gibbard PL (2015) Early-Middle Pleistocene transitions: linking terrestrial and marine realms. Quat Int 389:7-46

Head MJ, Pillans B, Farquhar SA (2008) The Early-Middle Pleistocene transition: characterization and proposed guide for the defining boundary. Episodes 31: $255-259$

Hedges JJ (2002) Sedimentary organic matter preservation and atmospheric $\mathrm{O}_{2}$ regulation. In: Gianguzza A, Pelizzetti E, Sammartano S (eds) Chemistry of Marine Water and Sediments. Springer-Verlag, 105-123

Hubbard SM, MacEachern JA, Bann KL (2012) Slopes. In: Knaust D, Bromley RG (eds) Trace Fossils as Indicators of Sedimentary Environments, Developments in Sedimentology vol, vol 64, pp 607-642

Hyodo M, Bradák B, Okada M, Katoh S, Kitaba I, Dettman DL, Hayashi H, Kumazawa K, Hirose K, Kazaoka O, Shikoku K, Kitamura A (2017) Millennial- 
scale northern Hemisphere Atlantic-Pacific climate teleconnections in the earliest Middle Pleistocene. Sci Rep 7:10036

Ito M (1992) High-frequency depositional sequences of the upper part of the Kazusa Group, a middle Pleistocene forearc basin fill in Boso Peninsula, Japan. Sediment Geol 76:155-175

Ito M, Katsura Y (1992) Inferred glacio-eustatic control for high-frequency depositional sequences of the Plio-Pleistocene Kazusa Group, a forearc basin fill in Boso Peninsula, Japan. Sediment Geol 80:67-75

Izumi K (2014) Utility of geochemical analysis of trace fossils: case studies using Phycosiphon incertum from the Lower Jurassic shallow-marine (Higashinagano Formation, southwest Japan) and Pliocene deep-marine deposits (Shiramazu Formation, central Japan). Ichnos 21:62-72

Izumi K, Suzuki R, Inui M (2017) Estimating the degree of mudstone compactional thinning: Empirical relationship between mudstone compaction and geochemical composition. Trans Kokushikan Univ Sci Eng Tokyo Japan 10:29-37

Kameo K, Kubota Y, Haneda Y, Suganuma Y, Okada M (2020) Calcareous nannofossil biostratigraphy of the Lower-Middle Pleistocene boundary of the GSSP, Chiba composite section in the Kokumoto Formation, Kazusa Group, and implications for sea-surface environmental changes. Prog Earth Planetary Sci 7:36

Katsura Y (1984) Depositional environments of the Plio-Pleistocene Kazusa Group, Boso Peninsula, Japan. Sci Rep Insti Geosci Univ Tsukuba Sec B Geol Sci 5:69-104

Kazaoka O, Suganuma Y, Okada M, Kameo K, Head MJ, Yoshida T, Kameyama S, Nirei H, Aida N, Kumai H (2015) Stratigraphy of the Kazusa Group, Central Japan: a high-resolution marine sedimentary sequence from the Lower to Middle Pleistocene. Quat Int 383:116-135

Keil RG, Hedges II (1993) Sorption of organic matter to mineral surfaces and the preservation of organic matter in coastal marine sediments. Chem Geol 107: 385-388

Kemp DB, Izumi K (2014) Multiproxy geochemical analysis of a Panthalassic margin record of the early Toarcian oceanic anoxic event (Toyora area, Japan). Palaeogeogr Palaeoclimatol Palaeoecol 414:332-341

Kennedy MJ, Pevear DR, Hill RJ (2002) Mineral surface control of organic carbon in black shale. Science 295:657-660

Kern JP (1978) Paleoenvironment of new trace fossils from the Eocene Mission Valley Formation, California. Jour Paleontol 52:186-194

Kido Y, Minami I, Tada R, Fujine K, Irino T, Ikehara K, Chun J-H (2007) Orbital-scale stratigraphy and high-resolution analysis of biogenic components and deepwater oxygenation conditions in the Japan Sea during the last $640 \mathrm{kyr}$. Palaeogeogr Palaeoclimatol Palaeoecol 247:32-49

Lisiecki LE, Raymo ME (2005) A Pliocene-Pleistocene stack of 57 globally distributed benthic $\delta^{18} \mathrm{O}$ records. Paleoceanography 20:PA1003

Locarnini RA, Mishonov AV, Antonov Jl, Boyer TP, Garcia HE, Baranova OK, Zweng MM, Paver CR, Reagan JR, Johnson DR, Hamilton M, Seidov D (2013) World Ocean Atlas 2013 volume 1: Temperature. In: Levitus S (ed) A Mishonov Technical Ed.; NOAA Atlas NESDIS 73, p 40

Löwemark L, Werner F (2001) Dating errors in high-resolution stratigraphy: a detailed X-ray radiograph and AMS $-{ }^{14} \mathrm{C}$ study of Zoophycos burrows. Mar Geol 177:191-198

Maasch KA (1988) Statistical detection of the mid-Pleistocene transition. Clim Dyn 2:133-143

Meyers PA (1994) Preservation of elemental and isotopic source identification of sedimentary organic matter. Chem Geol 114:289-302

Mudelsee M, Schulz M (1997) The Mid-Pleistocene climate transition: onset of 100 ka cycle lags ice volume build-up by 280 ka. Earth Planet Sci Lett 151: $117-123$

Mudelsee M, Stattegger K (1997) Exploring the structure of the mid-Pleistocene revolution with advanced methods of time-series analysis. Geol Rundsch 86: 499-511

Nakamura K, Takao A, Ito M (2007) Geometry and internal organization of hyperpycnites associated with a shelf-margin delta, the Middle Pleistocene Kokumoto Formation on the Boso Peninsula of Japan. J Sedimentological Soc Japan 64:65-68 (in Japanese with English abstract)

Niitsuma N (1976) Magnetic stratigraphy in the Boso Peninsula. Jour Geol Soc Japan 82:163-181 (in Japanese with English abstract)

Nishida N, Kazaoka O, Izumi K, Suganuma Y, Okada M, Yoshida T, Ogitsu I, Nakazato H, Kameyama S, Kagawa A, Morisaki M, Nirei H (2016) Sedimentary processes and depositional environments of a continuous marine succession across the Lower-Middle Pleistocene boundary: Kokumoto Formation, Kazusa Group, central Japan. Quat Int 397:3-15
Nomade S, Bassinot F, Marino M, Simon Q, Dewilde F, Maiorano P, Isguder G, Blamart D, Girone A, Scao V, Pereira A, Toti F, Bertini A, Combourieu-Nebout N, Peral M, Bourles DL, Petrosino P, Gallicchio S, Ciaranfi N (2019) High resolution foraminifer stable isotope record of MIS 19 at Montalbano Jonico, southern Italy: a window into Mediterranean climatic variability during a loweccentricity interglacial. Quat Sci Rev 205:106-125

Okada M, Niitsuma N (1989) Detailed paleomagnetic records during the BrunhesMatuyama geomagnetic reversal and a direct determination of depth lag for magnetization in marine sediments. Phy Ear Planet Int 56:133-150

Okada M, Suganuma Y, Haneda Y, Kazaoka O (2017) Paleomagnetic direction and paleointensity variations during the Matuyama-Brunhes polarity transition from a marine succession in the Chiba composite section of the Boso Peninsula, central Japan. Earth Planets Space 69(45). https://doi.org/10.1186/ s40623-017-0627-1

Raymo ME, Oppo DW, Curry W (1997) The Mid- Pleistocene climate transition: a deep sea carbon isotopic perspective. Paleoceanography 12:546-559

Riethdorf J-R, Nurnberg D, Max L, Tiedemann R, Gorbarenko SA, Malakhov MI (2013) Millennial-scale variability of marine productivity and terrigenous matter supply in the western Bering Sea over the past 180 kyr. Clim Past 9: $1345-1373$

Sakamoto T, Kuroki K, Sugawara T, Aoike K, lijima K, Sugisaki S (2006) Nondestructive $X$-ray fluorescence (XRF) core-imaging scanner, TATSCAN-F2. Sci Drill 2:37-39

Schlitzer R (2015) Ocean Data view. http://odv.awi.de.

Seilacher A (2007) Trace fossil analysis. Springer-Verlag, Berlin, p 226

Simon Q, Suganuma Y, Okada M, Haneda Y, Team ASTER (2019) High-resolution $10 \mathrm{Be}$ and paleomagnetic recording of the late polarity reversal in the Chiba composite section: age and dynamics of the Matuyama-Brunhes transition. Earth Planet Sci Lett 519:92-100

Suganuma Y, Haneda Y, Kameo K, Kubota Y, Hayashi H, Itaki T, Okuda M, Head MJ, Sugaya M, Nakazato $H$, Igarashi A, Shikoku K, Hongo M, Watanabe M, Satoguchi Y, Takeshita Y, Nishida N, Izumi K, Kawamura K, Kawamata M, Okuno J, Yoshida T, Ogitsu I, Yabusaki H, Okada M (2018) Paleoclimatic and paleoceanographic records through Marine Isotope Stage 19 at the Chiba composite section, central Japan: A key reference for the Early-Middle Pleistocene Subseries boundary. Quat Sci Rev 191:406-430

Suganuma Y, Okada M, Head M.J, Kameo K, Haneda Y, Hayashi H, Irizuki T, Itaki T, Izumi K, Kubota Y, Nakazato H, Nishida N, Okuda M, Satoguchi Y, Simon Q, Takeshita Y (2021) Formal ratification of the Global Boundary Stratotype Section and Point (GSSP) for the Chibanian Stage and Middle Pleistocene Subseries of the Quaternary System: the Chiba Section, Japan, Episodes, accepted

Suganuma Y, Okada M, Horie K, Kaiden H, Takehara M, Senda R, Kimura J, Haneda Y, Kawamura K, Kazaoka O, Head MJ (2015) Age of Matuyama-Brunhes boundary constrained by U-Pb zircon dating of a widespread tephra. Geology 43:491-494

Suganuma Y, Yamazaki T, Kanamatsu T, Hokanishi N (2008) Relative paleointensity record during the last $800 \mathrm{ka}$ from the equatorial Indian Ocean: implication for relationship between inclination and intensity variations. Geochem Geophys Geosyst 9:Q02011

Takao A, Nakamura K, Takaoka S, Fuse M, Oda Y, Shimano Y, Nishida N, Ito M (2020) Spatial and temporal variations in depositional systems in the Kazusa Group: insights into the origin of deep-water massive sandstones in a Pleistocene forearc basin on the Boso Peninsula, Japan. Prog Earth Planet Sci 7:37

Takeshita Y, Matsushima N, Teradaira H, Uchiyama T, Kumai H (2016) A marker tephra bed close to the Middle Pleistocene boundary: distribution of the Ontake-Byakubi tephra in central Japan. Quat Int 397:27-38

Tanaka I, Hyodo M, Ueno Y, Kitaba I, Sato H (2017) High-resolution diatom record of paleoceanographic variations across the Early-Middle Pleistocene boundary in the Chiba Section, central Japan. Quat Int 455:141-148

Tokuhashi S, Endo H (1984) Geology of Anesaki District with Geologic Map Sheet, 1:50,000. Geological Survey of Japan (in Japanese with English abstract)

Tyson RV, Pearson TH (1991) Modern and ancient continental shelf anoxia: an overview. In: Tyson RV, Pearson TH (eds) Modern and ancient continental shelf anoxia, Geol Soc Lond Spec Publ, vol 58, pp 1-26

Uchman A, Wetzel A (2012) Deep-sea fans. In: Knaust D, Bromley RG (eds) Trace fossils as indicators of sedimentary environments. developments in sedimentology, vol 64, pp 643-672

Wetzel A, Bromley RG (1994) Phycosiphon incertum revisited: Anconichnus horizontalis is junior subjective synonym. Jour Paleontol 68:1396-1402 
Wetzel A, Uchman A (2012) Hemipelagic and pelagic basin plains. In: Knaust D, Bromley RG (eds) Trace fossils as indicators of sedimentary environments, Developments in Sedimentology, vol 64, pp 673-702

Wilkin RT, Barnes HL, Brantley SL (1996) The size distribution of framboidal pyrite in modern sediments: an indicator of redox conditions. Geochim Cosmochim Acta 60:3897-3912

Xie X, Zheng HB, Qiao PJ (2014) Millennial climate changes since MIS 3 revealed by element records in deep-sea sediments from northern South China Sea. Chin Sci Bull 59:776-784

Yang S-K, Nagata Y, Taira K, Kawabe M (1993) Southward intrusion of the intermediate Oyashio water along the east coast of the Boso Peninsula I. Coastal salinity-minimum-layer water off the Boso Peninsula. Jour Oceanogr 49:89-114

Yang W, Zhou X, Xiang R, Wang Y, Shao D, Sun L (2015) Reconstruction of winter monsoon strength by elemental ratio of sediments in the East China Sea. Jour Asian Earth Sci 114:467-475

\section{Publisher's Note}

Springer Nature remains neutral with regard to jurisdictional claims in published maps and institutional affiliations.

\section{Submit your manuscript to a SpringerOpen ${ }^{\circ}$ journal and benefit from:}

- Convenient online submission

- Rigorous peer review

- Open access: articles freely available online

- High visibility within the field

Retaining the copyright to your article

Submit your next manuscript at $\boldsymbol{\nabla}$ springeropen.com 